\title{
METODE PEMBENTUKAN KEPRIBADIAN ISLAMI MENURUT SYAIKH TAQIYUDDIN AN-NABHANI
}

\author{
GUS DIN EL-HAQ, IWANDI \\ STAI Sultan Syarif Hasyim Siak \\ Iwandiibnnazir7@gmail.com
}

\begin{abstract}
Syaksiyah Islamiyah is an Islamic Personality. In Muslim scientific literature, the concept of Islamic personality has not been widely developed by Muslim scientific thinkers themselves, so this affects the difficulty of applying Islamic personality and methods of formation. Based on this, this paper contains the thoughts of Muslim leader Syaikh Taqiyuddin An-Nabhani about his views and ideas on the concept of Islamic personality and its method of formation. Islamic personality is formed by Islamic aqliyah and nafsiyah Islam. With the method of instilling Islamic aqeedah and tsaqofah Islam and habituation to always be bound by syara law '. Thus, the formation of Islamic personality is done by means of first compiling a curriculum based on Islamic faith, second, making Islamic theology as the basis of the subject matter, and third using the method of talaqqiyan fikriyan in the teaching process.
\end{abstract}

Keywords : Metode Pembentukan Kepribadian, Kepribadian Islam, Syaikh Taqiyuddin An-Nabhani

\section{PENDAHULUAN}

Sesungguhnya Allah Swt, telah menjadikan umat Islam sebagai umat yang terbaik. Sebagaimana firman Allah, dalam al-Qur'an:

"Kamu sekalian adalah sebaikbaik umat yang dilahirkan untuk manusia, yang menyuruh kepada yang ma'ruf dan mencegah dari yang munkar serta beriman kepada Allah" (TQS. Ali "Imrân: 110).
Umat Islam akan tetap menjadi umat yang terbaik ketika tetap berpegang teguh kepada al-Qur'an dan as-Sunnah, dan menjadikan keduanya sebagai pedoman dalam kehidupan serta menjadi sumber rujukan dalam setiap berpikir dan berbuat, karena keduanya adalah merupakan pusaka Rasulullah yang ditinggalkan kepada umatnya. 
Gus Din El-Haq, Iwandi; Metode Pembentukan Kepribadian Islami Menurut

Syaikh Taqiyuddin An-Nabhani

Sebagaimana Rasulullah Saw, telah bersabda:

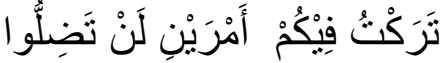

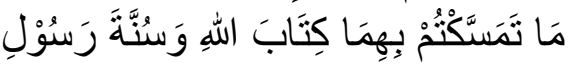

"Aku telah tinggalkan di tengah-tengah kalian dua perkara, kalian tidak akan tersesat selama berpegang kepada keduanya yakni kitabullah (al-Quran) dan Sunnah Rasulullah Saw." (HR. Muslim)

Dengan senantiasa terikat kepada akidah Islam dalam setiap berpikir dan berbuat. Maka seseorang akan memiliki kepribadian islami, yaitu pribadi yang senantiasa berfikir dan berbuat sesuai dengan akidah Islam serta menjalankan ajaran Islam secara kaffah. Sebagaimana perintah Allah Swt, dalam al-Qur'an:

"Hai orang-orang yang beriman, masuklah kalian ke dalam Islam secara keseluruhan, dan janganlah kalian mengikuti langkahlangkah setan. Sesungguhnya setan itu musuh yang nyata bagi kalian" (TQS. al-Baqarah : 208)

Menjadi pribadi yang islami dengan menjalankan Islam secara sempurna adalah merupakan anjuran dalam agama Islam. Hal ini karena Islam tidak hanya ajaran normatif yang hanya diyakini dan dipahami tanpa diwujudkan dalam kehidupan nyata. Islam memadukan antara keyakinan dan aplikasi, antara norma dan perbuatan, antara keimanan dan amal shaleh. Oleh karena itulah ajaran yang diyakini oleh umat Islam harus tercermin dalam setiap pemikiran, perbuatan dan sikap pribadi-pribadi umat Islam. Karena ummat Islam adalah merupakan makhluk ciptaan Allah Swt, yang mulia dan terbaik.
Sebagaimana telah dijelaskan dalam firman-Nya :

"Dan sesungguhnya telah Kami muliakan anak-anak Adam, Kami angkut mereka di daratan dan dilautan, Kami beri mereka rezki dari yang baik-baik dan Kami lebihkan mereka dengan kelebihan yang sempurna atas kebanyakan makhluk yang telah Kami ciptakan". (QS. AI Isra' : 70).

"Sesungguhnya Kami telah menciptakan manusia dalam bentuk yang sebaik-baiknya". (QS. At-Tin : 4).

Sebagai makhluk ciptaan yang mulia dan terbaik. Seorang muslim sudah seharusnya memiliki sifat dan perbuatan yang baik. Karena penilaian terhadap baik atau buruknya kepribadian seseorang akan dikembalikan kepada perbuatan-perbuatan yang dilakukannya. Seseorang yang mengakui dirinya sebagai seorang muslim sudah semestinya memiliki kepribadian islami. Artinya berfikir, bersikap dan berbuat sesuai dengan akidah Islam. Akan tetapi pada faktanya, orang-orang yang mengaku dirinya sebagai seorang muslim belum tentu ada jaminan pasti memiliki kepribadian islami. Jika kita melihat kondisi ummat Islam saat ini khusunya di Indonesia, tergambar dengan jelas betapa merosotnya kepribadian islami pada sebagian ummat Islam.

Realitas yang paling buruk dan berbahaya bagi ummat Islam saat ini adalah terjadinya krisis kepribadian yang sudah mencapai tahap kritis. lbarat penyakit kanker, telah mencapai stadium akhir. Bagaimana tidak, kerusakan moral yang melanda tidak dapat dibendung lagi dengan maraknya pergaulan bebas, free sex, budaya pacaran yang 
menjamur, narkoba, kriminal, perkosaan, pembunuhan, aliran sesat, korupsi dan berbagai krisis moral lainnya sedang terjadi saat ini. Sebagai contoh dari semua permasalahan krisis kepribadian di atas adalah sebagaimana menurut data Deputi Bidang Keluarga Berencana dan Kesehatan Reproduksi BKKBN (Badan Koordinasi Keluarga Berencana Nasional), Dr. Julianto Witjaksono SpOG, KFER, MGO pada 10 Agustus 2014 mengatakan 46 persen remaja berusia 15- 19 tahun belum menikah sudah berhubungan seks. Selain itu menurut data yang diperoleh dari BKKBN, sebanyak 20,9 persen remaja Indonesia mengalami kehamilan dan kelahiran sebelum menikah (Al-Islam, 2015). Semua perbuatan di atas sangat bertentangan dengan ajaran Islam dan sangat tidak mencerminkan kepribadian islami.

Inilah beberapa fakta krisis moral dan kepribadian Islam pada generasi Islam yang terjadi di Indonesia dewasa ini. Sungguh sangat ironis sekali karena krisis kepribadian Islam dan akhlak telah terjadi di semua lini termasuk kaum terpelajar. Terjadinya kerusakan moral dikalangan kaum terpelajar dewasa ini menunjukkan bahwa tujuan pendidikan Islam dalam rangka mencetak pribadi yang bermoral dan berkepribadian Islami belum tercapai.

Dari pemaparan di atas, menunjukkan bahwa untuk memiliki kepribadian islami yang sesuai dengan ajaran Islam membutuhkan usaha pembentukan dan pembinaan. Karena kepribadian islami pada seseorang tidak datang dengan sendirinya, membutuhkan pembinaan dan pembentukan secara serius. Oleh karena itu dibutuhkan konsep kepribadian islami dan metode pembentukannya yang jelas, sehingga dapat diaplikasikan dalam kehidupan lingkungan keluarga maupun pendidikan dalam rangka membentuk kepribadian islami.

Berdasarkan penjelasan di atas, penulis tertarik meneliti, mengkaji dan menganalisis sebuah gagasan, pemikiran dan pandangan dari ilmuan muslim yaitu, Syaikh Taqiyuddin An-Nabhani, tentang konsep dan metode pembentukan kepribadian islami. Ada beberapa hal yang menarik dari gagasan, pemikiran dan pandangan Syaikh Taqiyuddin an-Nabhani, tentang konsep kepribadian islami dan metode pembentukannya. Sehingga menurut penulis penting untuk diteliti, dikaji dan dianalisis, diantaranya adalah sebagai berikut:

$$
\text { Pertama, pandangan Syaikh }
$$

Taqiyuddin an-Nabhani tentang konsep kepribadian islami dan metode pembentukannya memiliki kekhasan tersendiri dan berbeda dari konsep kepribadian dalam pandangan psikologi barat. Syaikh Taqiyuddin an-Nabhani dalam membangun konsep kepribadian islami dan metode pembentukannya dengan terlebih dahulu mengkaji manusia secara mendalam kemudian membangunnya dengan merujuk kepada al-Qur'an dan asSunnah berdasarkan akidah Islam.

Kedua, Syaikh Taqiyuddin anNabhani mengkritik dan membantah teori-teori konsep keribadian psikologi barat. Beliau menjelaskan, pandangan yang dibangun berdasarkan ilmu psikologi barat yang secara keseluruhannya keliru dari berbagai sisi (An-nabhani, 2002). Dengan demikian, 
pandangan yang keliru yang dijadikan landasan dalam memandang kepribadian manusia, pada akhirnya mengantarkan kepada kekeliruan dalam memahami hakikat kepribadian manusia itu sendiri. Disamping itu, menurut Syaikh Taqiyuddin an-Nabhani nilainilai yang terkandung dalam ilmu psikologi barat sebagian bertentangan dengan pemikiran Islam (An-nabhani, 2002). Berkenaan dengan hal tersebut, Syaikh Taqiyuddin an-Nabhani berpandangan harus adanya perombakan terhadap tolak ukur keyakinan dan pemikiran umat Islam dengan cara kembali kepada tsaqofah Islam. Tolak ukur yang dimaksud adalah tolak ukur Islam dan mendorong untuk kembali kepada akidah Islam.

Ketiga, menurut Syaikh Taqiyuddin an-Nabhani kepribadian manusia tidak ada kaitannya dengan bentuk tubuh, wajah dan asesori lain sejenisnya, bagi yang menganggap hal itu semua sebagai pembentuk dan mempengaruhi kepribadian merupakan pemikiran yang sangat dangkal dan keliru. Karena semua itu hanya penampakan kulit luar belaka (An-nabhani, 2003). Lalu seperti apakah konsep kepribadian menurut Syaikh Taqiyuddin anNabhani tersebut. Hal ini sangat penting untuk dikaji dan dianalisis, guna mendapatkan konsep kepribadian islami yang sesunggguhnya.

Keempat, gagasan dan pandangan Syaikh Taqiyuddin anNabhani tentang konsep kepribadian islami dan metode pembentukannya berbeda dengan konsep kepribadian psikologi barat, bahkan Syaikh Taqiyuddin an-Nabhani membantah konsep kepribadian menurut psikologi barat. Hal ini sangat menarik sekali untuk dikaji dan diteliti secara mendalam. Seperti apakah sebenarnya konsep kepribadian islami dan metode pembentukannya yang ditawarkan oleh Syaikh Taqiyuddin an-Nabhani tersebut. Sehingga kajian penelitian ini diharapkan mampu menghasilkan sebuah konsep kepribadian islami dan metode pembentukannya dalam pandangan ilmuan muslim, kemudian dari hasil penelitian ini dapat diterapkan dan diaplikasikan dalam dunia pendidikan maupun lingkungan keluarga dalam membentuk generasi yang memiliki kepribadian islami sekaligus menjadi teori kepribadian dalam khazanah keilmuan Islam.

1. Pembentukan berasal dari kata "bentuk", yakni rupa atau gambaran sesuatu yang memiliki ciri khas. Dalam penelitian ini yang dimaksud dengan pembentukan adalah upaya yang dilakukan untuk membentuk kepribadian islami, yaitu mewujudkan pemikiran dan perbuatan seseorang yang sesuai dengan akidah Islam. Sehingga memiliki ciri khas kepribadian islami.

2. Kepribadian Islami

Kepribadian dalam beberapa bahasa disebut dengan istilah personality (Inggris); personalidad (Spanyol); dan personalichkeit (Jerman). Berasal dari kata Latin yaitu, "persona" yang berarti topeng (Mujib, 1999). Dalam bahasa Arab, Syakhshiyah berasal dari kata "syakhsh" yang berarti "pribadi". Kata itu kemudian diberi yâ' an-nisbah sehingga menjadi kata benda buatan 


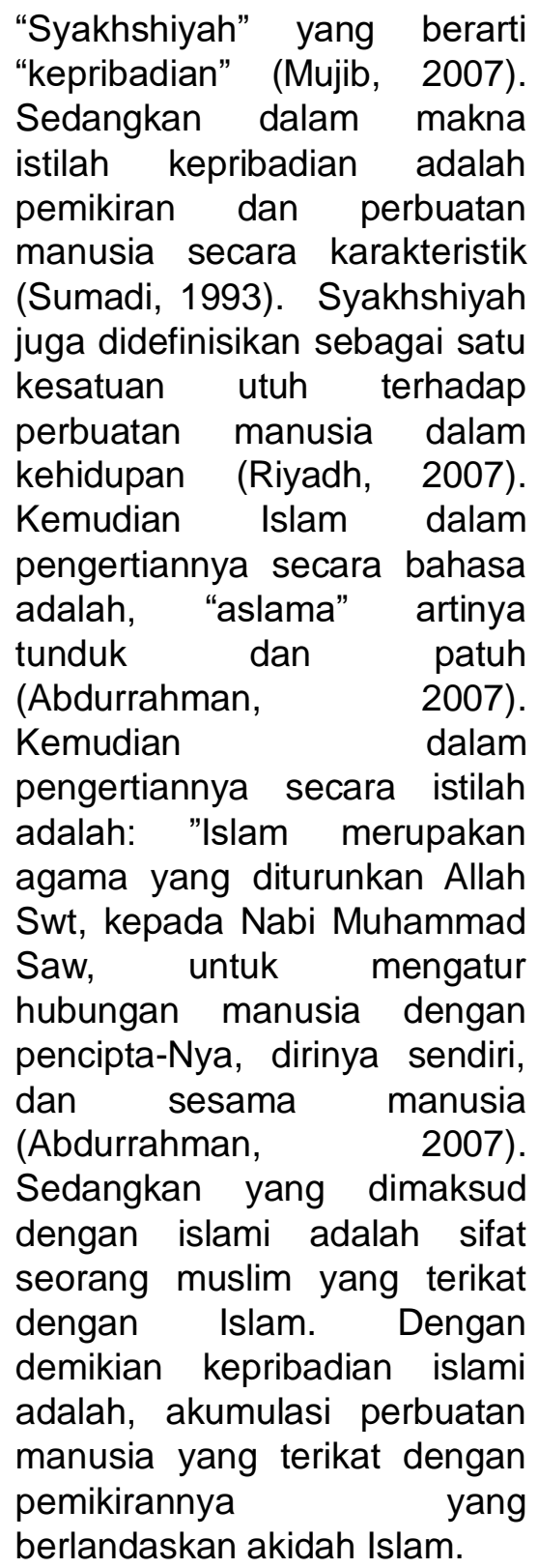

3. Syaikh Taqiyuddin an-Nabhani, adalah seorang qadli, penyair, sastrawan, politisi ulung dan salah seorang ulama terkemuka dalam Daulah Utsmaniyyah. Nama lengkapnya Muhammad Taqiyyuddin bin Ibrahim bin Musthofa bin Ismail bin Yusuf an-Nabhani, lahir tahun 19091977. Namanya dinisbahkan kepada kabilah bani Nabhan keturunan Arab di Palestina, yaitu daerah ljzim termasuk wilayah Haifa di Palestina Utara (Dodiman, 2012).

\section{BIOGRAFI SYAIKH TAQIYUDDIN AN-NABHANI}

\section{Nama dan Nasabnya.}

Syaikh Taqiyuddin an-Nabhani adalah seorang âlim allâmah (berilmu dan sangat luas keilmuannya). Nama lengkapnya adalah Syaikh Taqiyuddin bin Ibrahim bin Mushthafa bin Ismail bin Yusuf an-Nabhani. Nasab beliau bernisbatkan kepada kabilah Bani Nabhan, salah satu kabilah Arab di Palestina yang mendiami kampung ljzim, distrik Shafad, termasuk wilayah kota Hayfa di Utara Palestina.

Beliau dinasabkan termasuk di antara keluarga dari kalangan terhormat, yang hidup di desa ljzim, selatan kota Haifa, wilayah jajahan Kiral Mahral tahun 1949. Keluarga beliau adalah keluarga yang memiliki kedudukan tinggi dalam hal ilmu pengetahuan dan agama. Nasab keluarga beliau kembali pada keluarga besar an-Nabhani dari Kabilah al-Hanajirah di Bi'r as-Sab'a. Banu keturunan Nabhan merupakan orang kepercayaan Bani Samak dari keturunan Lakhm yang tersebar di wilayah-wilayah Palestina. Sedang Lakhm adalah Malik bin Adiy. Mereka memiliki bangsa dan suku yang banyak. Pada akhir abad ke-2 Masehi sekelompok dari Bani Lakhm tiba di Palestina bagian selatan (Muhsin, 2012).

\section{Kelahiran dan Pertumbuhan Syaikh Taqiyuddin an-Nabhani}

Syaikh Taqiyuddin an-Nabhani dilahirkan di desa ljzim pada tahun 1909 M. Beliau tumbuh dan besar di rumah yang sangat memperhatikan 
ilmu dan agama. Ayah beliau Syaikh Ibrahim an-Nabhani adalah seorang Syaikh yang faham agama, dan sebagai tenaga pengajar ilmu-ilmu syariah di Kementrian Pendidikan Palestina. Sementara ibu beliau juga menguasai beberapa cabang ilmu syariah, yang diperolehnya dari ayahnya, Syaikh Yusuf an-Nabhani (1265 H. - 1350 H./1849 M. - 1932 M.). Beliau adalah Asy-Syaikh Yusuf bin Ismail bin Yusuf bin Ismail bin Hasan bin Muhammad an-Nabhani asy-Syafi'i. julukannya Abul Mahasin. Beliau seorang penyair, sastrawan, sufi dan salah seorang qadhi yang terkemuka. Nasabnya pada kabilah Bani Nabhan, satu kabilah Arab penghuni padang sahara di Palestina. Mereka bermukim di daerah ljzim dengan shighot amar wilayah Haifa, Palestina Selatan. Di sinilah beliau dilahirkan dan dibesarkan. Beliau belajar di Al-Azhar, Mesir (1283$1289 \quad$ H.). Beliau memimpin peradilan (qadha') di Qushban Janin, wilayah Nablus. Kemudian beliau berpindah ke Konstantinopel. Beliau bekerja sebagai redaktur dan editor surat kabar al-Jawanib. Beliau diangkat sebagai qadhi di Kawa Sinjiq, wilayah Moshul. Beliau kebali ke negeri Syam (1269 H.). Beliau berpindah-pindah bekerja di peradilan hingga beliau menjabat sebagai Ketua Mahkamah al-Huquq di Beirut $(1305 \mathrm{H})$. Di Beirut ini beliau tinggal lebih dari sepuluh tahun. Kemudian beliau pergi ke kota-kota tetangga, ketika itu perang dunia pertama sedang berkecamuk. Lalu beliau kembali ke tempat kelahirannya, ljzim. Di ljzim ini beliau wafat, 29 Ramadhan 1350 H. AsySyaikh Yusuf an-Nabhani banyak meninggalkan kekayaan intelektual. Beliau menulis di bidang tashawuf, sastra, hadits, sejarah dan tafsir. Di Dar Kutub al-Mishriyah ditemukan sekitar 67 kitab karya beliau. Dan sebagian besar kitabnya ditulis ketika beliau tinggal di Beirut, $48 \mathrm{di}$ antaranya telah dicetak, yang sebagian besar dicetak di Beirut dan Kairo, salah seorang di antara para ulama yang menonjol di Daulah Utsmaniyah. Syaikh Taqiyuddin mendapat perhatian dan pengawasan langsung oleh kakeknya dari jalur ibunya, yaitu Syaikh Yusuf bin Ismail an-Nabhani.

$$
\text { Pertumbuhan keagamaan }
$$

yang dialami oleh Syaikh Taqiyuddin berpengaruh besar terhadap pembentukan kepribadiannya, orientasi dan pandangan keagamaannya. Sehingga beliau telah hafal al-Qur'an sebelum berumur 13 tahun. Beliau banyak belajar ilmu agama dari kakeknya dan dari kakeknya pula, beliau banyak mengerti persoalanpersoalan politik, dimana kakeknya memiliki keahlian dalam hal ini. Beliau juga banyak belajar dari forum-forum dan diskusi-diskusi fiqih yang diadakan kakeknya, AsySyaikh Yusuf an-Nabhani, khususnya diskusi tentang orangorang yang telah mengidolakan peradaban Barat. Kakeknya telah melihat tanda-tanda kecerdasan dan kejeniusannya, yaitu ketika Syaikh Taqiyuddin ikut dalam forum-forum ilmu, sehingga perhatian sang kakek kepadanya sangat besar sekali (Muhsin, 2012).

\section{IImu dan Pendidikan Syaikh Taqiyuddin an-Nabhani \\ Syaikh Taqiyuddin belajar} dasar-dasar ilmu syariah dari ayah dan kakeknya. Di samping itu, beliau juga belajar di sekolah negeri anNizhomiyah di daerah ljzim untuk sekolah tingkat dasar. Kemudian, 
beliau melanjutkan studinya ke sekolah tingkat menengah di Akka. Belum selesai studinya pada tingkat menegahnya di Akka, beliau pergi ke Kairo untuk meneruskan studinya di Al-Azhar, guna merealisasikan keinginan kakeknya, Syaikh Yusuf an-Nabhani, yang telah menyakinkan ayahnya tentang pentingnya mengirim Syaikh Taqiyuddin ke Al-Azhar untuk melanjutkan pendidikan agamanya. Kemudian, Syaikh Taqiyuddin meneruskan pendidikan tingkat menengahnya di Al-Azhar pada tahun 1928, dan lulus dengan memperoleh ijazah dengan predikat sangat memuaskan. Setelah lulus dari sekolah tingkat menengah, lalu Syaikh Taqiyuddin melanjutkan studinya di Fakultas Darul Ulum, yang ketika itu masih merupakan filial Al-Azhar. Di samping itu, beliau juga aktif menghadiri kelompokkelompok kajian (halaqoh-halaqoh) ilmiyah di Al-Azhar, yang diadakan oleh para asy-Syaikh, seperti yang telah disarankan oleh kakeknya, di antaranya, kelompok kajian yang diadakan Syaikh Muhammad alHidhir Husain. Hal itu dimungkinkan karena sistem pengajaran yang lama di Al-Azhar membolehkannya. Di mana para mahasiswa dapat memilih beberapa Syaikh Al-Azhar dan menghadiri halaqoh-halaqoh mereka mengenai bahasa dan ilmuilmu syariah, di antaranya fiqih, ushul fiqih, hadits, tafsir, tauhid (ilmu kalam), dan yang sejenisnya.

$$
\text { Syaikh }
$$

Taqiyuddin menyelesaikan kuliahnya di Fakultas Darul Ulum tahun 1932 M. Dan pada tahun yang sama, beliau juga selesai kuliahnya di Al-Azhar sesuai dengan sistem yang lama. Syaikh Taqiyuddin sangat menarik perhatian kawan-kawannya dan para dosennya, karena kesungguhannya dalam belajar dan kecermatannya dalam berpikir serta kuatnya hujjah yang dilontarkan dalam berpendapat, dalam perdebatanperdebatan, dan diskusi-diskusi pemikiran, baik yang diselenggarakan oleh lembagalembaga ilmu yang ada saat itu di Kairo maupun di negeri-negeri Islam lainnya (Muhsin, 2012).

4. Ijazah-ljazah yang diperoleh Syaikh Taqiyuddin an-Nabhani

Syaikh Taqiyuddin an-Nabhani memperoleh banyak ljazah, yaitu: ljazah dengan predikat sangat memuaskan dari sekolah tingkat menengah (ast-tsanawiyah) AlAzhar, Diploma jurusan bahasa Arab dan sastranya dari Fakultas Darul Ulum Kairo, dan Diploma dari alMa'had al-Ali li al-Qadha' asy-Syar'iy filial Al-Azhar jurusan peradilan. Tahun 1932 beliau lulus dari AlAzhar dengan memperoleh asySyahadah al"Alamiyah (ljazah setingkat Doktor) pada jurusan syariah (Muhsin, 2012).

\section{Karakteristik dan Sifat Syaikh Taqiyuddin an-Nabhani}

Syaikh Taqiyuddin an-Nabhani adalah seorang yang jujur, mulia, bersih, ikhlas, bersemangat, bergelora dan merasa pedih atas apa yang menimpa umat Islam akibat dari ditanamnya institusi Israil di dalam jantung mereka. Beliau seorang yang sedang perawakannya, kuat fisiknya, penuh semangat, cepat marah, pandai dalam perdebatan, yang jika berargumentasi mematikan, dan tegas dengan sesuatu yang diyakininya benar. Beliau berjenggot sedang bercampur uban serta selalu berpakaian dengan pakaian para ulama: jubah (pakaian panjang dipakai di atas jubah), dan sorban. 
Beliau seorang yang berkepribadian kuat, bicaranya menyentuh, dan argumentasinya menyakinkan. Beliau sangat benci dengan perbuatan yang sia-sia, kurangnya percaya diri, serta ketidakpedulian terhadap kemaslahatan umat. Beliau juga sangat membenci seseorang yang hanya sibuk dengan kepentingannya sendiri dan tidak beraktivitas untuk kebaikan umat.

Sementara karakteristik aktivitas beliau di bidang pengajaran, Syaikh Taqiyuddin anNabhani mengajarkan materi tsaqofah Islam pada sekolah menengah kelas tiga, mengingat pada saat itu merupakan tahapan pertumbuhan sensitivitas yang akan membentuk pola pikir siswa. Sehingga beliau melaksanakan aktivitasnya dengan sebaik mungkin. Beliau melakukan aktivitas ini siang malam dengan kebiasaan yang mengagumkan. Aktivitas ini beliau jalankan sampai beliau meletakkan jabatan sebagai tenaga pengajar di Fakultas pada akhir tahun $1952 \mathrm{M}$. Sungguh metode pengajarannya sangat sukses dan menghasilkan sesuatu yang positif dalam diri para siswanya. Sehingga para siswanya sangat mencintai kajian-kajian tsaqofah Islam yang menjadikan mereka memiliki berbagai persiapan untuk mengkritisi setiap pemikiranpemikiran asing yang masuk ke dalam Islam. Begitu juga, kecintaan mereka terhadap kajian-kajian tsaqofah Islam akan membentuk landasan berfikir, yang dengannya mereka mampu mencerminkan ajaran-ajaran Islam dan mengembannya ke seluruh dunia.

Syaikh Taqiyuddin an-Nabhani adalah seorang yang bertakwa dan mulia seperti namanya. Beliau seorang yang mampu menjaga pandangan matanya dan lisannya. Beliau tidak suka memcaci, mencela atau menghina salah seorang di antara kaum muslimin, khususnya para pengemban dakwah Islam, meski mereka berbeda hasil ijtihadnya (Muhsin, 2012).

\section{Bidang Pekerjaan dan Jabatan Syaikh Taqiyuddin an-Nabhani}

Bidang pekerjaan Syaikh Taqiyuddin an-Nabhani, terbatas antara pendidikan dan peradilan (qadha'). Beliau banyak menduduki jabatan pada dua bidang ini. Setelah selesai studinya, Syaikh Taqiyuddin an-Nabhani kembali ke Palestina untuk bekerja di Kementrian Pendidikan Palestina sebagai tenaga pengajar pada sekolah menengah an-Nidzomiyah di Haifa, disamping beliau juga mengajar di sekolah al-Islamiyah yang juga di Haifa. Beliau berpindah-pindah lebih dari satu kota dan sekolah sejak tahun $1932 \mathrm{M}$, hingga tahun $1938 \mathrm{M}$. Dimana beliau mengajukan permohonan untuk bekerja di Mahkamah Syariah. Karena beliau menyaksikan bahwa pengaruh penjajahan Barat di bidang pendidikan jauh lebih banyak daripada pengaruhnya di bidang peradilan, khususnya, peradilan syariah. Dalam hal ini beliau berkata: "Adapun golongan terpelajar, maka para penjajah di sekolah sekolah misionarisnya sebelum adanya pendudukan, dan diseluruh sekolah setelah adanya pendudukan, telah menetapkan sendiri kurikulum-kurikulum pendidikan dan tsaqofah (kebudayaan) berdasarkan filsafatnya, serta peradabannya dan konsep-konsep kehidupannya yang khas. Kemudian kepribadian ala Barat dijadikan dasar yang akan mencabut tsaqofah (dari umat 
Islam). Sebagaimana sejarah dan kebangkitan Barat dijadikan sumber utama, yang dengannya mereka mencuci otak kita" (An-nabhani, 2002).

Oleh karena itu, Syaikh Taqiyuddin an-Nabhani meninggalkan bidang pendidikan pada Kementrian Pendidikan. Beliau mulai mencari dan mengkaji pekerjaan lain yang lebih sedikit mendapatkan pengaruh Barat. Beliau tidak menemukan yang lebih baik dari Mahkamah Syariah. Sebab, Mahkamah Syariah seperti yang beliau lihat masih menerapkan hukum-hukum syara'. Syaikh Taqiyuddin an-Nabhani berkata:

"Adapun sistem sosial yang mengatur hubungan pria dan wanita, serta apa saja yang timbul dari adanya hubungan ini, yakni masalah-masalah perdata, maka Mahkamah Syariah masih menerapkan syari'at Islam hingga sekarang, meski adanya penjajahan dan pemerintahan kufur. Secara umum hingga sekarang belum pernah diterapkan selain syariat Islam (An-nabhani, 2001)".

Syaikh Taqiyuddin an-Nabhani akhirnya diangkat sebagai sekretaris di Mahkamah Syariah Beisan, lalu beliau dipindah ke Thabriya. Namun demikian, cita-cita dan pengetahuan beliau di bidang peradilan mendorongnya untuk mengajukan kepada Al-Majlis Al-Islamiy Al-A'la (Dewan Tertinggi Islam) sebuah nota permohonan. Setelah para pimpinan peradilan memperhatikan nota permohonannya, mereka memutuskan untuk memindahnya ke Haifa dengan jabatan sebagai Kepala Sekretaris, tepatnya di Mahkamah Syariah Haifa. Kemudian tahun 1940 beliau diangkat sebagai Musyawir, yakni asisten qadhi.
Beliau tetap dengan jabatan itu hingga tahun 1945, di mana beliau dipindah ke Mahkamah Syariah di Ramallah, dan beliau tetap di sana hingga tahun 1948. Setelah itu beliau pergi meninggalkan Ramallah menuju Syam sebagai akibat dari jatuhnya Palestina ke tangan Yahudi. Pada tahun 1948 itu juga, sahabatnya Al-Ustadz Anwar alKhatib mengirim surat kepada beliau yang isinya meminta beliau agar kembali ke Palestina untuk dianggkat sebagai qadhi di Mahkamah Syariah AI-Quds. Syaikh Taqiyuddin an-Nabhani mengabulkan sahabatnya itu. Dan beliau pun diangkat Mahkamah Syariah Al-Quds tahun 1948. Kemudian, Kepala Mahkamah Syariah dan Kepala Mahkamah Isti'naf yang ketika itu dijabat oleh alUstadz Abdul Hamid as-Sa'ih memilihnya sebagai anggota di Mahkamah Isti'naf (Pengadilan Banding). Beliau tetap menduduki jabatan itu hingga tahun 1950.

Kemudian, pada tahun 1951, Syaikh Taqiyuddin an-Nabhani datang ke Amman, dan bekerja sebagai tenaga pengajar di Fakultas al-Imiyah al-Islamiyah. Beliau dipilih untuk mengajar materi tsaqofah Islam bagi para mahasiawa tingkat dua di Fakultas tersebut. Aktivitasnya ini terus berlangsung hingga awal tahun 1953, di mana beliau mulai sibuk dengan aktivitas Hizbut Tahrir yang telah beliau rintis antara tahun 1949 hingga tahun 1953 (Muhsin, 2012).

\section{Mendirikan Hizbut Tahrir}

Barangkali peristiwa yang paling menonjol dalam sejarah kehidupan Syaikh Taqiyuddin anNabhani adalah berdirinya Hizbut Tahrir. Unsur-unsur terpenting yang 
dimiliki Syaikh Taqiyuddin anNabhani, yang menjadikan beliau punya posisi penting dan istimewa dalam sejarah para pengemban dakwah yang beraktivitas demi tegaknya agama ini, yaitu dengan mendirikan Hizbut Tahrir yang hingga kini masih tetap berdiri di atas dasar yang dibuat sendiri oleh Syaikh Taqiyuddin an-Nabhani. Unsur-unsur utama itu di antaranya:

a. Lingkungan keagamaan Syaikh Taqiyuddin an-Nabhani dilahirkan dan dibesarkan. Membuat beliau mulai sejak kecil telah ditanamkan agama dan kencintaan kepada agama di bawah asuhan ayahnya, ibunya, dan kakeknya dari jalur ibu, Syaikh Yusuf an-Nabhani. Hal ini memberi pengaruh besar bagi Syaikh Taqiyuddin an-Nabhani dalam meretas jalan yang akan ditempuhnya di masa selanjutnya.

b. Posisi keilmuan dan politik yang digeluti Syaikh Yusuf an-Nabhani berpengaruh besar terhadap tumbuhnya kesadaran politik Syaikh Taqiyuddin an-Nabhani dengan begitu cepatnya. Sehingga tidak lama kemudian menjadikan beliau berada di barisan para politisi yang telah teruji dan berpengalaman.

c. Syaikh Taqiyuddin an-Nabhani benar-benar menyaksikan dan merasakan sendiri bencana runtuhnya Khilafah, musibahmusibah yang menimpa umat Islam, tercerai-berainya tubuh mereka, rakusnya penjajah terhadap mereka, dan jatuhnya Palestina tahun 1948 ke tangan kelompok gangster Yahudi; suksesnya serangan pemikiran dan peradaban barat, serta sikap para ulama kaum muslimin yang hanya menggunakan retorika- retorika pembelaan terhadap Islam dalam menghadapai serangan yang genting ini, bahkan mereka mena'wilkan nash-nash Islam, yang justru turut membantu memperkuat pemikiran barat, sebaliknya menggoncang kepercayaan umat terhadap Islam sebagai sebuah sistem kehidupan. Sehingga, Syaikh Taqiyuddin an-Nabhani di sela-sela studinya di al-Azhar bertanya, menguji dan mengkaji tentang sebab keadaan yang menimpa kaum muslimin, serta menguji dan mengkaji metode yang benar untuk mengubah realitas yang rusak ini, di samping itu mengembalikan bangunan istana yang tinggi (Khilafah Islam), yang telah dihancurkannya oleh orang-orang kafir.

d. Pendidikan dan ilmu Syaikh Taqiyuddin an-Nabhani yang diperoleh dari ayah dan kakeknya, ditambah berbagai disiplin ilmu yang beliau himpun selama masa studinya di Al-Azhar dengan sistemnya yang lama dan yang baru telah memberi peluang yang cukup besar kepada Syaikh Taqiyuddin an-Nabhani untuk meneliti dan mengkaji berbagai gerakan lama, utamanya gerakan-gerakan baru yang berusaha melakukan perbaikan. Hal inilah yang banyak membantu langkah beliau selanjutnya dalam menyusun garis-garis pokok bagi sebuah kelompok partai yang akan beraktivitas membangkitkan umat.

e. Syaikh Taqiyuddin an-Nabhani selama masa studinya di AlAzhan, serta aktivitasnya di bidang pendidikan dan peradilan mampu mengenal banyak 
karakteristik ulama, ahli fikir dan politisi, yang darinya dibentuk landasan utama bagi partai yang akan didirikannya. Perkaraperkara ini semuanya terkumpul dalam diri Syaikh Taqiyuddin anNabhani, sementara hasilnya, Syaikh Taqiyuddin an-Nabhani telah meninggalkan partai yang besar, kuat dan tersebar luas, serta menjadikan partai ini sebagai kekuatan Islam yang luar biasa yang benar-benar diperhitungkan oleh para pemikir dan para politisi, baik lokal maupun internasional (Muhsin, 2012).

\section{Karya-karya Syaikh Taqiyuddin an-Nabhani}

Syaikh Taqiyuddin an-Nabhani meninggalkan banyak kitab-kitab penting, yang dianggap sebagai peninggalan intelektual yang luar biasa dan tak ternilai harganya. Karya-karya beliau ini menunjukkan bahwa beliau merupakan sosok pribadi yang pikiran dan sensitivitasnya di atas rata-rata dan tiada duanya. Beliaulah yang menulis setiap pemikiran dan konsep Hizbut Tahrir, baik yang terkait hukum-hukum syara' maupun yang terkait masalah-masalah pemikiran, politik, ekonomi dan sosial. Dan inilah yang mendorong sebagian peneliti untuk mengatakan bahwa Hizbut Tahrir itu adalah Taqiyuddin an-Nabhani. Karya-karya Syaikh Taqiyuddin an-Nabhani kebanyakan berupa kitab-kitab yang sifatnya pembentukan teori dan pembuatan rencana, atau buku-buku yang isinya dimaksudkan sebagai seruan untuk melanjutkan kembali kehidupan yang islami (sesuai syariat Islam), dengan terlebih dahulu menegakkan Daulah Islamiyah (Negara Islam).
Oleh karena itu, kitab-kitab karya Syaikh Taqiyuddin an-Nabhani menjadi istimewa dan unik, disebabkan isinya yang komprehensip mencakup semua aspek kehidupan dan problematika manusia, baik aspek kehidupan individu khususnya, maupun aspek politik, pendidikan, perundangundangan, sosial dan ekonomi pada umumnya. Selanjutnya karya-karya beliau ini dijadikan dalil (landasan) pemikiran dan politis bagi Hizbut Tahrir, di mana Syaikh Taqiyuddin an-Nabhani sebagai motornya. Karena banyaknya bidang-bidang kajian dalam kitab-kitab yang ditulis oleh Syaikh Taqiyuddin an-Nabhani, maka hasil pemikirannya yang berupa kitab jumlahnya lebih dari 30 buah kitab. Ini tidak termasuk notanota politis yang berisi pemecahan terhadap problem-problem yang sifatnya politik, serta penyususnan rencana yang urgen. Dan banyak lagi selebaran-selebaran dan penjelasan-penjelasan yang sifatnya pemikiran dan politik yang penting. Karya-karya Syaikh Taqiyuddin anNabhani menjadi istimewa karena ditulis dengan penuh kesadaran, kecermatan, dan kejelasan, di samping metodologinya yang khas yang menonjolkan Islam sebagai sebuah teori idiologis yang konprehensif, yang digali dari dalildalil syar'iy yang terkandung dalam al-Qur'an maupun as-Sunnah. Karya-karya Syaikh Taqiyuddin anNabhani yang sifatnya pemikiran, dianggap sebagai sebuah usaha keras pertama, yang dipersembahkan oleh seorang pemikir muslim dengan metodenya yang khas pada era modern ini. Karya-karya Syaikh Taqiyuddin anNabhani yang paling terkenal menonjol, yang berisikan pemikiran- 
pemikiran dan ijtihad-ijtihad beliau, yaitu:

(1) Nizham al-Islam, (2) atTakattul al-Hizbiy, (3) Mafahim Hizb at-Tahrir, (4) an-Nizham al-lqtishadiy fi al-Islam, (5) an-Nizham al-ljtima'iy fi al-Islam, (6) Nizham al-Hukm fi alIslam, (7) ad-Dustur, (8) Muqaddimah ad-Dustur, (9) adDaulah al-Islamiyah, (10) AsySyakhshiyah al-Islamiyah tiga jilid, (11) Mafahim Siyasah li al-Hizb atTahrir, (12) Nazhorat as-Siyasiyah, (13) Nida' Har, (14) al-Khilafah, (15) at-Tafkir, (16) al-Kurrasah, (17) Sur'ah al-Badihah, (18) Nuqthah alIntilaq, (19) Dukhul al-Mujtama', (20) Inqadz al-Filasthin, (21) Risalah alArab, (22) Tasalluh Mishr, (23) alIttifaqiyat ats-Tsuna'iyah al-Mishriyah as-Suriyah wa al-Yamaniyah, (24) Halla Qadhiyah Filasthin ala athThariqah al-Amirikiyah wa alInjiliziyah, (25) Nazhoriyah al-Faragh as-Siyasiy haula Iznahawur, (26) asSiyasah al-lqtishadi al-Mutsla, (27) Naqdhu al-Istirakiyan al-Markisiyah, (28) Kaifa Hudimat al-Khilafah, (29) Nizhom al-Uqubat, (30) Ahkam ashShalah, (31) Ahkam al-Bayyinat, (32) al-Fikr al-Islamiy, (33) Naqdh alQanun al-Madaniy. Di samping itu, masih ada ribuan selebaran yang sifatnya pemikiran, politik dan ekonomi. Banyak di antara bukubuku beliau yang dikeluarkan atas nama anggota Hizbut Tahrir, dengan tujuan agar buku-buku itu mudah disebarluaskan, setelah adanya undang-undang yang melarang buku-buku beliau dan peredarannya di masa itu. Di antara buku-buku itu adalah: (1) Naqdh al-Qanun alMadaniy, (2) Ahkam ash-Shalah, alFikr al-Islamiy, (3) as-Siyasah allqtishadi al-Mutsla, (4) Naqdhu alIstirakiyan al-Markisiyah, (5) Kaifa Hudimat al-Khilafah, (6) Ahkam al-
Bayyinat, dan (7) Nizhom al-Uqubat (Muhsin, 2012).

\section{Akidah dan Mazhab Syaikh Taqiyuddin an-Nabhani}

Sehubungan dengan akidah Syaikh Taqiyuddin an-Nabhani, maka dapat disimpulkan melalui pembahasan terhadap topik-topik akidah Islam yang terdapat dalam kitab beliau asy-Syakhshiyah alIslamiyan jilid pertama, Syaikh Taqiyuddin an-Nabhani menjelaskan bahwa rukun iman itu ada enam: iman kepada Allah, iman kepada para malaikat-Nya, iman kepada kitab-kitab-Nya, iman kepada para Rasul-Nya, iman kepada hari akhir, dan iman kepada qadha' dan qadar, di mana baik buruk keduanya dari Allah Swt. Dan hal itu juga ditemukan ketika membahas topik, wahyu (An-nabhani, 2003) dan lainnya. Sedangkan madzhab Syaikh Taqiyuddin an-Nabhani, maka belum ditemukan sumber yang jelas, yang menjelaskan tentang madzhab beliau. Namun dapat dikatakan bahwa Syaikh Taqiyuddin an-Nabhani mazhabnya adalah mazhab Syafi'iy. Pendapat ini didasarkan pada bahwa sejak kecil beliau telah dididik oleh kakeknya, Yusuf an-Nabhani, sedang Yusuf anNabhani mazhabnya adalah Syafi'iy. Sebelumnya telah disebutkan bahwa Syaikh Taqiyuddin an-Nabhani belajar di Al-Azhar. Beliau memadukan dua sistem Al-Azhar yang lama dan sistem yang baru di Darul Ulum. Beliau mempelajari kitab-kitab yang ada di perpustakaan Al-Azhar ketika itu, mulai dari bahasa, ushul fiqih hingga bidangbidang yang lainnya. Dari pengkajian dan penelitian beliau yang luas ini, maka memungkinkan bagi beliau untuk membuat kaidah-kaidah khas beliau sendiri dalam ilmu ushul fiqih 
yang didasarkan pada kuatnya dalil yang menurut penilaian beliau paling kuat. Beliau mengkritisi banyak kaidah syara' dengan menjelaskan kesalahan beberapa kaidah, menjelaskan keabsahan sebagian, dan meluruskan sebagian yang lain. Sementara metode ijtihad beliau didasarkan pada pertama meneliti fakta dan memahami realita, baru kemudian mempelajari nash-nash syara' yang terkait dengan fakta dan realita tersebut, serta memeriksanya untuk memperkuat bahwa nashnash tersebut datang membawa hukum atas realita yang hendak dipecahkannya, selanjutnya memahami makna-makna nash sesuai data-data bahasa Arab, setelah itu baru ditetapkan hukum syara' yang diambil dari nash-nash ini. Beliau konsisten dengan metode ini dalam berijtihad, sehingga menjadikan ketenangan dan kepuasan senantiasa menyertainya, bahwa hukum-hukum yang digalinya adalah hukum-hukum syara' yang ditopang dengan kekuatan dalil syara'.

Oleh karena itu, beberapa peneliti menganggap Syaikh Taqiyuddin an-Nabhani adalah seorang mujtahid. Termasuk keistimewaan metode Syaikh Taqiyuddin an-Nabhani dalam menggali hukum dan berijtihad adalah menjadikan realita sebagai tempat berfikir bukan sumber bagi penetapan hukumnya, menundukkan realita untuk dipecahkan dengan hukum syara', dan membentuk realita sejalan dengan Islam, serta tidak menjadikan hukum syara' mengikuti realita, sebagaimana yang banyak dilakukan oleh para ulama kontemporer yang sering menarik ulur nash-nash untuk menyesuaikan dengan realita, serta untuk menyenangkan nafsu para penguasa. Syaikh Taqiyuddin anNabhani tidak tergolong di antara orang-orang yang melihat bahwa pendapatnya saja yang benar sementara pendapat orang lain salah, apalagi sesat, tetapi beliau melihat pendapatnya benar namun tidak menutup kemungkinan salah, sebaliknya pendapat orang lain salah namun tidak menutup kemungkinan benar. Inilah yang menjadikan beliau banyak mendengarkan pendapat-pendapat yang lain, mengkaji dan menelitinya, meski beliau tetap percaya dengan pendapatnya (Muhsin, 2012).

\section{Posisi Keilmuan Syaikh} Taqiyuddin an-Nabhani

Posisi keilmuan Syaikh Taqiyuddin an-Nabhani terlihat dengan jelas sekali melalui karyakaryanya yang beragam, yang mencakup semua kebutuhankebutuhan hidup yang amat sangat diperlukan umat di jalan kebangkitan, dan mengembalikan kedudukan umat Islam pada kedudukan yang seharusnya di antara umat-umat yang lain. Dari karya-karya ini tampak bahwa beliau berupaya melakukan pembaharuan yang belum pernah dilakukan sebelumnya di berbagai bidang: pemikiran, fiqih, dan politik. Oleh karena itu, karya-karya Syaikh Taqiyuddin an-Nabhani yang sifatnya pemikiran dianggap sebagai sebuah usaha keras pertama yang dipersembahkan oleh seorang pemikir muslim dengan metodenya yang khas pada era modern ini. Dengan begitu, Syaikh Taqiyuddin an-Nabhani merupakan tokoh di antara tokoh pemikir dan politik pada abad dua puluh. Sehingga tidaklah aneh jika ada orang yang 
memasukkan Syaikh Taqiyuddin anNabhani dalam golongan ulama mujtahid mujaddid. Sayyid Quthub pernah menyanjung dan memuji Syaikh Taqiyuddin an-Nabhani di salah satu forum ilmiah yang beliau pimpinnya.

Sanjungan dan pujian beliau ini merupakan bentuk penolakan atas sikap banyak orang yang mulai menyerang dan merendahkan Syaikh Taqiyuddin an-Nabhani. Di antara pernyataan Sayyid Quthub terkait Syaikh Taqiyuddin anNabhani adalah: "Sesungguhnya Syaikh ini, yakni Taqiyuddin anNabhani dengan kitab-kitabnya telah sampai pada derajat ulama-ulama kita terdahulu".

Kemudian, Al-Ustadz Dr. Muhammad bin Abdullah al-Masari menggambarkan Syaikh Taqiyuddin an-Nabhani dengan perkataan: "Tokoh pembaharu, teladan para ulama yang ikhlas dalam beramal dan Beliaulah yang telah meletakkan batu pondasi untuk pemikiran Islam modern yang luhur dan pergerakan yang ikhlas yang memiliki kesadaran tinggi. Semoga Allah mengangkat derajatnya bersama para Nabi, shiddiqin, para syahid dan orangorang shaleh" (Muhsin, 2012).

\section{Wafatnya Syaikh Taqiyuddin an- Nabhani}

Syaikh Taqiyuddin an-Nabhani enggan hidup sebagai penulis yang karya-karyanya hanya untuk melengkapi koleksi perpustakaanperpustakaan, pengarang yang hasilnya hanya untuk dipelajari, peneliti yang hanya sebatas menemukan kebenaran, berkarir di bidang politik, atau sebagai pengajar politik, namun beliau ingin hidup sebagai peneliti dan penulis untuk menyadarkan umat dan membangkitkannya berdasarkan
Islam, memerangi serangan pemikiran dan peradaban yang telah merasuk ke tengah-tengah para pelajar dalam waktu yang lama, berusaha keras membebaskan umat dari penjajahan pemikiran, frustasi dan serangan budaya, selanjutnya mengurusi urusan umat dengan Islam, setelah umat kembali lagi percaya dengan Islam dan solusisolusinya.

Syaikh Taqiyuddin an-Nabhani menegaskan bahwa berkelompok dan berorganisasi harus di atas ideologi, agar ikatannya dalam berpartai adalah ikatan ideologis bukan ikatan (hubungan) pribadi. Sebab, hanya dengan cara ini dapat dijamin keberlangsungan dan kesatuan (keutuhan) partai, serta kelurusan kepemimpinan yang memimpinnya. Dengan ikatan ideologis ini, siapapun tidak memiliki otoritas selain terikat dengan fikroh dan thoriqoh (pemikiran dan pelaksanaannya), juga penilaian atas orang-orang yang tergabung dalam partai itu hanya berdasarkan pelayanan dan pegabdiannya terhadap ideologi, serta kreatifitasnya dalam merealisasikan tujuannya, dan menyatunya dengan pemikirannya. Oleh karena itu, Syaikh Taqiyuddin an-Nabhani menolak kepribadiannya dan ilmunya dijadikan topik pembahasan dan diskusi. Namun, meski demikian, Syaikh Taqiyuddin anNabhani mengharuskan dirinya menyelami berbagai bidang pengetahuan, sehingga menghasilkan karya-karya ilmiyah yang istimewa meliputi bidang fiqih, pemikiran dan politik. Dengan begitu, Syaikh Taqiyuddin anNabhani merupakan tokoh di antara tokoh pemikir dan politik pada abad dua puluh (An-nabhani, 2010). 
Syaikh Taqiyuddin an-Nabhani menghabiskan dua dekade kehidupannya yang terakhir sebagai orang yang terasing, terusir dan buronan yang dijatuhi hukuman mati (Muhsin, 2012). Namun, semua itu tidak menghalanginya dari beraktivitas secara terus-menerus, serta kegiatan-kegiatan secara serius dan tekun, dalam rangka menyebarkan pemikiran-pemikiran Hizbut Tahrir yang beliau dirikan, dan merealisasikan tujuannya berupa kembalinya kehidupan yang sesuai syari'at Islam dengan terlebih dahulu mendirikan Khilafah di atas metode kenabian. Seorang anggota Majlis Palestina, Muhammad Dawud Audah menceritakan bahwa Syaikh Taqiyuddin an-Nabhani adalah seorang yang fakir, dan beliau wafat dalam keadaan fakir. Beliau tinggal di lantai lima pada sebuah apartemen. Beliau dengan rendah hati menaiki apartemennya dengan jalan kaki, sebab di apartemen itu masih belum ada lift. Di awal-awal dekade tujuh puluhan Syaikh Taqiyuddin an-Nabhani pergi ke Irak. Beliau ditahan tidak lama setelah adanya kampanye besarbesaran penangkapan terhadap para anggota Hizbut Tahrir di Irak. Namun para penguasa tidak mengetahui bahwa beliau adalah Syaikh Taqiyuddin an-Nabhani pemimpin Hizbut Tahrir. Beliau disiksa dengan siksaan yang keras hingga beliau tidak mampu lagi berdiri karena banyaknya siksaan. Bahkan beliau merupakan tahanan terakhir di antara tahanan Hizbut Tahrir yang mereka bantu untuk berdiri ketika dikembalikan ke penjara. Beliau terus-menerus mendapatkan siksaan hingga beliau mengalami kelumpuhan setengah badan (hemiplegia).
Kemudian beliau dibebaskan dan segera ke Lebanon. Di Lebanon beliau mengalami kelumpuhan pada otak. Tidak lama kemudian beliau dilarikan ke rumah sakit dengan menggunakan nama samaran. Dan di rumah sakit inilah Syaikh Taqiyuddin an-Nabhani wafat pada tangga 1 Muharram $1398 \mathrm{H}$. atau tanggal 11 Desember $1977 \mathrm{M}$. Beliau dikebumikan di pekuburan asy-Syuhada di Hirsy Beirut (Muhsin, 2012).

\section{METODE PEMBENTUKAN KEPRIBADIAN ISLAMI MENURUT SYAIKH TAQIYUDDIN AN- NABHANI \\ 1. Metode Kepribadian Islami Secara Umum}

Menurut Syaikh Taqiyuddin anNabhani, kepribadian setiap manusia terbentuk dari aqliyah dan nafsiyahnya. Sedangkan kepribadian islami dibentuk oleh aqidah Islam, dengan aqidah Islam inilah terbentuk aqliyah dan nafsiyahnya. Kemudian dibangun dengan tsaqofah Islam, dan setelah itu senantiasa terikat dengan akidah dan tsaqofah Islam tersebut. Inilah metode pembentukan kepribadian islami dan ini pula metode yang ditempuh oleh Rasulullah Saw.

Rasulullah Saw, berdakwah mengajak manusia untuk memeluk Islam kemudian menanamkan aqidah Islam. Setelah itu Rasul memperhatikan keterikatan aqliyah dan nafsiyah kaum muslimin dengan aqidah Islam (An-nabhani, 2010). Kemudian Rasulullah menjelaskan ayat-ayat Allah yang diturunkan kepadanya berupa al-Qur'an dan menjelaskan hukum-hukum serta mengajarkan Islam terhadap kaum muslim. Melalui pembinaan yang 
dilakukan oleh Rasulullah inilah terbentuk pribadi-pribadi yang islami sesuai yang beliau bawa, syakhshiyah-syakhshiyah tertinggi yang ada di alam semesta ini setelah syakhshiyah para Nabi (Annabhani, 2003).

Berdasarkan penjelasan di atas, metode pembentukan kepribadian islami secara umum dilakukan dengan tiga metode, pertama menanamkan aqidah Islam, kedua menanamkan tsaqofah Islam, dan ketiga senantiasa membangun keterikatan aqliyah dan nafsiyah dengan akidah dan tsaqofah Islam. Selanjutnya dijelaskan sebagai berikut:

\section{a. Metode Menanamkan Akidah Islam}

Syaikh Taqiyuddin an-Nabhani, mendefinisikan akidah Islam adalah: "Iman kepada Allah, malaikat-Nya, kitab-kitab-Nya, para Rasul-Nya, hari akhir, dan qodha' qodar baik dan buruk keduanya dari Allah Swt (Annabhani, 2003)". Kemudian Syaikh Taqiyuddin an-Nabhani mendefinisikan iman adalah: "Pembenaran yang bersifat pasti yang sesuai dengan fakta berdasarkan dalil. Terkait dengan iman, Syaikh Taqiyuddin an-Nabhani menegaskan, ketika pembenaran terhadap sebuah fakta tidak disertai dalil, maka tidak digolongkan iman, karena tidak termasuk pembenaran yang bersifat pasti. Berdasarkan hal ini, keimanan harus disertai dengan dalil agar melahirkan pembenaran yang bersifat pasti. Ini berarti adanya dalil terhadap segala sesuatu yang dituntut untuk diimani harus mutlak adanya, agar pembenaran terhadap sesuatu tadi tergolong iman. Dengan demikian, adanya dalil merupakan syarat pokok adanya keimanan. Oleh karena itu, metode dalam menanamkan akidah Islam pada seseorang harus disertai dengan dalil. Kemudian Syaikh Taqiyuddin an-Nabhani menjelaskan bahwa, dalil dapat digolongkan kedalam dua kategori utama, yaitu, dalil 'aqli dan dalil naqli (An-nabhani, 2003).

1) Menanamkan Akidah Islam dengan Dalil Aqli

Dalil aqli adalah suatu pembuktian yang bisa dibuktikan oleh akal untuk mencapai sebuah pembenaran yang bersifat pasti (attashdiq al-Jazim) pada salah satu rukun dari rukun-rukun iman (akidah) (Husen, 2006). Adapun rukun-rukun iman (akidah) yang dibuktikan dengan dalil aqli ada tiga yaitu, iman terhadap keberadaan Allah Swt, iman bahwa al-Qur'an berasal dari Allah Swt, dan iman bahwa Muhammad adalah utusan Allah Swt.

a) Dalil Aqli Iman Kepada Allah Swt

Dengan al-Qur'an, Allah telah membimbing manusia kepada jalan yang dapat membuat manusia memahami atau menyadari keberadaan Allah Swt, Allah telah memerintahkan manusia untuk berfikir dan menggunakan akalnya, sebagaimana firmannya:

"Apakah mereka tidak memperhatikan unta, bagaimana ia diciptakan? dan langit, bagaimana ia ditinggikan? dan gunung-gunung, bagaimana ia ditegakkan? dan bumi, bagaimana ia dihamparkan?". (TQS. Al-Ghasyiyah [88]: 17-20).

"Hendaklah danusia
memperhatikan dari apa ia
diciptakan? (TQS. At-Thariq [86]:
5)


Katakanlah: "Berjalanlah di (muka) bumi, Maka perhatikanlah bagaimana Allah menciptakan (manusia) dari permulaannya. (TQS. al-Ankabut [29] : 20)

Banyak lagi ayat serupa lainnya, yang mengajak manusia untuk memperhatikan bendabenda alam dengan seksama, dan melihat apa yang ada di sekelilingnya maupun yang berhubungan dengan keberadaan dirinya. Ajakan itu untuk dijadikan petunjuk akan adanya pencipta yang maha pengatur, sehingga imannya kepada Allah Swt menjadi iman yang mantap, yang berakar pada akal dan bukti yang nyata. Dengan demikian setiap muslim wajib menjadikan imannya betul-betul muncul dari proses berfkir, selalu meneliti dan memperhatikan serta senantiasa bertahkim (merujuk) kepada akalnya secara mutlak dalam beriman kepada (adanya) Allah Swt. Ajakan untuk memperhatikan alam semesta dengan seksama, dalam rangka mencari sunatullah serta untuk memperoleh petunjuk agar beriman terhadap penciptanya, telah disebut ratusan kali oleh al-Qur'an dalam berbagai surat yang berbeda. Semuanya ditujukan kepada potensi akal manusia untuk diajak berfkir dan merenung, sehingga imannya betul-betul muncul dari akal dan bukti yang nyata. Disamping untuk memperingatkannya agar tidak mengambil jalan yang telah ditempuh oleh nenek moyangnya, tanpa meneliti dan menguji kembali sejauh mana kebenarannya. Inilah iman yang diserukan oleh Islam. Iman semacam ini bukanlah seperti yang dikatakan orang sebagai imannya orang-orang lemah, melainkan iman yang berpijak pada pemikiran yang cemerlang dan meyakinkan, yang senantiasa mengamati (alam sekitarnya), berpikir dan berpikir. Melalui pengamatan dan perenungannya akan sampai kepada keyakinan tentang adanya Allah yang maha kuasa.

Keimanan terhadap keberadaan Allah Swt, sebagai sang pencipta (al-Khaliq) adalah merupakan perkara aqidah yang mendasar dalam Islam. Karena Islam dibangun diatas satu dasar, yaitu akidah Islam. Akidah Islam menjelaskan bahwa di balik alam semesta, manusia, dan kehidupan, terdapat sang pencipta (al-Khaliq) yang telah meciptakan ketiganya, serta yang telah meciptakan segala sesuatu lainnya. Dialah Allah Swt. Bahwasanya Pencipta telah menciptakan segala sesuatu dari tidak ada menjadi ada. la bersifat wajibul wujud, wajib adanya. Sebab, kalau tidak demikian, berarti la tidak mampu menjadi Khaliq. la bukanlah makhluk, karena sifat-Nya sebagai pencipta memastikan bahwa diri-Nya bukan makhluk. Pasti pula bahwa la mutlak adanya, karena segala sesuatu menyandarkan wujud atau eksistensinya kepada diriNya; sementara la tidak bersandar kepada apapun. Bukti bahwa segala sesuatu mengharuskan adanya pencipta yang menciptakannya, dapat dijelaskan dengan proses berfkir, sebagai dalil aqli sebagai berikut:

Segala sesuatu yang dapat dijangkau oleh akal terbagi dalam tiga unsur, yaitu manusia, alam 
semesta, dan hidup. Ketiga unsur ini bersifat terbatas lemah, serba kurang, dan saling membutuhkan kepada yang lain. Misalnya, manusia terbatas sifatnya, karena ia tumbuh dan berkembang sampai pada batas tertentu yang tidak dapat dilampuinya lagi. Ini menunjukkan bahwa manusia bersifat terbatas. Begitu pula halnya dengan hidup, bersifat terbatas, karena penampakannya bersifat individual. Apa yang kita saksikan selalu menunjukkan bahwa hidup ini berakhir pada satu individu saja. Jadi, hidup juga bersifat terbatas. Sama halnya dengan alam semesta yang memiliki sifat terbatas. Alam semesta merupakan himpunan dari benda-benda angkasa, yang setiap bendanya memiliki keterbatasan. Himpunan segala sesuatu yang terbatas, tentu terbatas pula sifatnya. Jadi, alam semesta pun bersifat terbatas. Walhasil, manusia, hidup, dan alam semesta, ketiganya bersifat terbatas. Apabila kita melihat kepada segala sesuatu yang bersifat terbatas, akan kita simpulkan bahwa semuanya tidak azali. Jika bersifat azali (tidak berawal dan tidak berakhir), tentu tidak mempunyai keterbatasan. Dengan demikian segala yang terbatas pasti diciptakan oleh "sesuatu yang lain". "Sesuatu yang lain" inilah yang disebut alKhaliq. Dialah yang menciptakan manusia, hidup, dan alam semesta. Dalam menentukan keberadaan pencipta ini akan kita dapati tiga kemungkinan. Pertama, la diciptakan oleh yang lain. Kedua, la menciptakan diriNya sendiri. Ketiga, la bersifat azali dan wajibul wujud.
Kemungkinan pertama bahwa la diciptakan oleh yang lain adalah kemungkinan yang bathil, tidak dapat diterima oleh akal. Sebab, bila benar demikian, tentu la bersifat terbatas. Begitu pula dengan kemungkinan kedua, yang menyatakan bahwa la menciptakan diri-Nya sendiri. Jika demikian berarti Dia sebagai makhluk dan Khaliq pada saat yang bersamaan. Hal yang jelasjelas tidak dapat diterima. Karena itu, al-Khaliq harus bersifat azali dan wajibul wujud. Dialah Allah Swt. Siapa saja yang mempunyai akal akan mampu membuktikan hanya dengan adanya bendabenda yang dapat diinderanya bahwa di balik benda-benda itu pasti terdapat pencipta yang telah menciptakannya. Fakta menunjukkan bahwa semua benda itu bersifat serba kurang, sangat lemah, dan saling membutuhkan. Hal ini menggambarkan segala sesuatu yang ada hanyalah makhluk. Jadi untuk membuktikan adanya alKhaliq yang maha pengatur, sebenarnya cukup hanya dengan mengarahkan perhatian manusia terhadap benda-benda yang ada di alam semesta, fenomena hidup, dan diri manusia sendiri. Dengan mengamati salah satu planet yang ada di alam semesta, atau dengan merenungi fenomena hidup, atau meneliti salah satu bagian dari diri manusia, akan kita dapati bukti nyata dan meyakinkan akan adanya Allah Swt. Karena itu, dalam al-Qur'an terdapat ajakan untuk mengalihkan perhatian manusia terhadap benda-benda yang ada, seraya mengajaknya turut mengamati dan 
memfokuskan perhatian terhadap benda-benda tersebut dan segala sesuatu yang ada di sekelilingnya, atau yang berhubungan dengannya, agar dapat membuktikan adanya Allah Swt. Dengan mengamati bendabenda tersebut, bagaimana satu dengan yang lain saling membutuhkan, akan memberikan suatu pemahaman yang meyakinkan dan pasti, akan adanya Allah Yang Maha Pencipta lagi Maha Pengatur.

Kendati wajib atas manusia menggunakan akalnya dalam mencapai iman kepada Allah Swt, namun tidak mungkin ia menjangkau apa yang ada di luar batas kemampuan indera dan akalnya. Sebab akal manusia terbatas. Terbatas pula kekuatannya sekalipun meningkat dan bertambah sampai batas yang tidak dapat dilampauinya; terbatas pula jangkauannya. Melihat kenyataan ini, maka perlu diingat bahwa akal tidak mampu memahami Zat Allah dan hakekat-Nya. Sebab, Allah Swt berada di luar ketiga unsur pokok (alam semesta, manusia, dan hidup) tadi. Sedangkan akal manusia tidak akan mampu memahami apa yang ada di luar jangkauannya. la tidak akan mampu memahami Zat Allah Swt. Dengan demikian, akal tidak mungkin memahami hakekat yang ada di luar batas kemampuannya, karena perannya amat terbatas. Seharusnya keterbatasannya itu justru menjadi faktor penguat iman, bukan sebaliknya malah menjadi penyebab keragu-raguan dan kebimbangan. Apabila iman kita kepada Allah Swt telah dicapai melalui proses berfikir dan disertai dengan dalil-dalil, maka kesadaran kita terhadap adanya Allah Swt menjadi sempurna. Begitu pula jika perasaan hati kita mengisyaratkan adanya Allah, lalu dikaitkan dengan akal dan dalil, tentu perasaan tersebut akan mencapai suatu tingkat yang meyakinkan. Bahkan hal itu akan memberikan suatu pemahaman yang sempurna serta perasaan yang meyakinkan terhadap sifat-sifat ketuhanan. Dengan sendirinya, cara tersebut akan meyakinkan kita bahwa manusia tidak sanggup memahami hakekat Zat Allah. Sebaliknya hal ini justru akan memperkuat iman kita kepadaNya. Disamping keyakinan seperti ini, kita wajib berserah diri terhadap semua yang dikhabarkan Allah Swt tentang hal-hal yang yang tidak sanggup dicerna atau yang tidak dapat dicapai oleh akal. Ini disebabkan lemahnya akal manusia yang memiliki ukuran-ukuran yang serba terbatas kemampuannya, untuk memahami apa yang ada di luar jangkauan akalnya. Padahal untuk memahami hal semacam ini, diperlukan ukuran-ukuran yang tidak terbatas, yang justru tidak dimiliki dan tidak akan pernah dimiliki manusia (Annabhani, 2001).

Dengan demikian, iman terhadap keberadaan Allah Swt dicapai dengan dalil aqli. Namun keimanan terhadap sifat-sifat Allah dapat dicapai melalui dalil naqli, yaitu wahyu Allah Swt. Sebagaimana dijelaskan dalam al-Qur'an:

"Dialah Allah yang tiada Tuhan selain Dia, Raja, yang 
Maha Suci, yang Maha Sejahtera, yang Mengaruniakan Keamanan, yang Maha Memelihara, yang Maha Perkasa, yang Maha Kuasa, yang memiliki segala Keagungan, Maha suci Allah dari apa yang mereka persekutukan. Dialah Allah yang Menciptakan, yang Mengadakan, yang membentuk Rupa, yang mempunyai nama-nama yang baik (asma-ul Husna). Bertasbih kepadanya apa yang di langit dan bumi. dan Dialah yang Maha Perkasa lagi Maha Bijaksana". (TQS. al-Hasyr [59]: 23-24)

b) Dalil Aqli Iman Kepada al-Qur'an Berasal dari Allah Swt

Dalil yang menunjukkan bahwa al-Qur'an itu berasal dari Allah dan al-Qur'an merupakan Kalamullah adalah dalil aqli, karena al-Qur'an adalah sesuatu yang bisa diindera, dan memungkinkan bagi akal untuk menjangkau bahwa keberadaannya dari sisi Allah Swt (An-nabhani, 2001). Mengenai bukti bahwa al-Qur'an itu datang dari Allah, dapat dilihat dari kenyataan bahwa al-Qur'an adalah sebuah kitab berbahasa Arab yang dibawa oleh Rasulullah Muhammad Saw. Dalam menentukan darimana asal alQur'an, akan kita dapatkan tiga kemungkinan.

Pertama, kitab itu adalah karangan orang Arab. Kedua, karangan Muhammad Saw. Ketiga, berasal dari Allah Swt. Tidak ada lagi kemungkinan selain dari yang tiga ini. Sebab, al-Qur'an adalah berciri khas Arab, baik dari segi bahasa maupun gayanya. Kemungkinan pertama yang mengatakan bahwa al-Quran adalah karangan orang
Arab, tidak dapat diterima. Sebab, al-Qur'an sendiri telah menantang mereka untuk membuat karya yang serupa. Sebagaimana firman Allah Swt:

"Bahkan mereka mengatakan: "Muhammad telah membuat-buat al-Qur'an itu", Katakanlah: "(Kalau demikian), Maka datangkanlah sepuluh surat-surat yang dibuat-buat yang menyamainya, dan panggillah orang-orang yang kamu sanggup (memanggilnya) selain Allah, jika kamu memang orang-orang yang benar". (TQS. Hud : 13)

"Dan jika kamu (tetap) dalam keraguan tentang al-Quran yang Kami wahyukan kepada hamba Kami (Muhammad), buatlah satu surat (saja) yang semisal al-Qur'an itu dan ajaklah penolong-penolongmu selain Allah, jika kamu orang-orang yang benar". (TQS. al-Baqarah [2]: 23)

"Atau (patutkah) mereka mengatakan: 'Muhammad membuat-buatnya'. Katakanlah: '(Kalau benar yang kamu katakan itu), maka cobalah datangkan sebuah surat seumpamanya dan panggillah siapa-siapa yang dapat kamu panggil (untuk membuatnya) selain Allah, jika kamu orang-orang yang benar'. (TQS. Yunus [10]:38)

"Katakanlah:

'Sesungguhnya jika manusia dan jin berkumpul untuk membuat yang serupa al-Qur'an ini, niscaya mereka tidak akan dapat membuat yang serupa dengan dia, sekalipun sebagian mereka menjadi pembantu bagi sebagian yang lain'. (TQS. al-Isra [17] : 88) 
Orang-orang Arab telah berusaha keras mencobanya, akan tetapi tidak berhasil. Hal ini membuktikan bahwa al-Qur'an bukan berasal dari perkataan mereka. Mereka tidak mampu menghasilkan karya yang serupa, kendati ada tantangan dari alQur'an dan mereka telah berusaha menjawab tantangan itu.

Kemungkinan kedua yang mengatakan bahwa Al-Qur'an itu karangan Muhammad Saw, juga tidak dapat diterima oleh akal. Sebab, Muhammad Saw adalah orang Arab juga. Bagaimanapun jeniusnya, tetap ia sebagai seorang manusia yang menjadi salah satu anggota dari masyarakat atau bangsanya. Selama seluruh bangsa Arab tidak mampu menghasilkan karya yang serupa, maka masuk akal pula apabila Muhammad yang juga termasuk salah seorang dari bangsa arab tidak mampu menghasilkan karya yang serupa. Karena itu, jelas bahwa al-Qur'an itu bukan karangannya. Terlebih lagi dengan adanya banyak hadits-hadits shahih yang berasal dari Nabi Muhammad Saw, yang sebagian malah diriwayatkan lewat cara yang tawatur yang kebenarannya tidak diragukan lagi. Apabila setiap hadits ini dibandingkan dengan ayat manapun dalam al-Qur'an, maka tidak akan dijumpai adanya kemiripan dari segi gaya bahasanya. Padahal Nabi Muhammad Saw, disamping selalu membacakan setiap ayatayat yang diterimanya, dalam waktu yang bersamaan juga mengeluarkan hadits. Namun, ternyata keduanya tetap berbeda dari segi gaya bahasanya. Bagaimanapun kerasnya usaha seseorang untuk menciptakan berbagai macam gaya bahasa dalam pembicaraannya, tetap saja akan terdapat kemiripan antara gaya yang satu dengan yang lain, karena merupakan bagian dari ciri khasnya dalam berbicara. Karena tidak ada kemiripan antara gaya bahasa alQur'an dengan gaya bahasa hadits, berarti al-Qur'an itu bukan perkataan Nabi Muhammad Saw. Masing-masing dari keduanya terdapat perbedaan yang tegas dan jelas. Itulah sebabnya tidak seorang pun dari bangsa Arab orang-orang yang paling tahu gaya dan sastra bahasa Arab pernah menuduh bahwa alQur'an itu perkataan Muhammad Saw, atau mirip dengan gaya bicaranya. Satu-satunya tuduhan yang mereka lontarkan adalah bahwa al-Qur'an itu disadur Muhammad Saw dari seorang pemuda Nasrani yang bernama Jabr. Tuduhan ini telah ditolak keras oleh Allah Swt dalam frman-Nya:

"Dan sesungguhnya Kami mengetahui bahwa mereka berkata: "Sesungguhnya alQur'an itu diajarkan oleh seorang manusia kepadanya

(Muhammad)". Padahal bahasa orang yang mereka tuduhkan (bahwa) Muhammad belajar kepadanya bahasa 'Ajam, sedang Al Qur'an adalah dalam bahasa Arab yang terang. (TQS. An-Nahl [16]: 103).

Apabila telah terbukti bahwa al-Qur'an itu bukan karangan bangsa Arab, bukan pula karangan Muhammad Saw, berarti al-Qur'an itu adalah 
kalamullah, yang menjadi mukjizat bagi orang yang membawanya dan karena Nabi Muhammad Saw, adalah orang yang membawa al-Qur'an yang merupakan kalamullah dan syariat Allah, serta tidak ada yang membawa syariat-Nya melainkan para Nabi dan Rasul, maka berdasarkan dalil aqli dapat diyakini secara pasti bahwa Muhammad Saw itu adalah seorang Nabi dan Rasul (Annabhani, 2001).

Dengan demikian dalil tentang keimanan bahwa alQur'an berasal dari Allah Swt, dan sebagai kalamullah adalah dalil aqli. Namun dalil terhadap kitab-kitab samawi yang lain, dalilnya adalah dalil naqli (Annabhani, 2003). Didalam alQur'an Allah telah memberitahukan kepada kita bahwa, Allah telah menurunkan kitab Zabur kepada Nabi Daud As, kitab Taurat kepada Nabi Musa As, kitab Injil kepada Nabi Isa As, dan Shuhuf kepada Nabi Ibrahim As. Sebagaimana dijelaskan dalam al-Qur'an :

"Dan Kami berikan Zabur kepada Daud". (TQS. al-Isra [17] : 55)

"Dan (Allah menurunkan Taurat dan Injil. Sebelum (AI Qur'an), menjadi petunjuk bagi manusia”. (TQS. Ali-Imran [3] : 34)

"Sesungguhnya ini benarbenar terdapat dalam Kitab-Kitab yang dahulu, yaitu Shuhuf Ibrahim dan Musa". (TQS. al-A'la [87] : 18-19)

"Wahai orang-orang yang beriman tetaplah beriman kepada Allah dan Rasul-Nya dan kepada kitab yang Allah turunkan kepada
RasulNya, serta kepada kitab yang Allah turunkan sebelumnya". (TQS. an-Nisa [4]: 136)

"Sesungguhnya kebajikan itu ialah beriman kepada Allah, hari kemudian, malaikat-malaikat, kitab-kitab, nabi-nabi". (TQS. alBaqarah [2]: 177)

Demikianlah dalil-dalil

berkenaan dengan kitab-kitab samawi lainnya yang telah diturunkan untuk umat nabi-nabi sebelum umat Nabi Muhammad Saw. Keimanan terhadap kitab alQur'an dengan keimanan terhadap kitab-kitab sebelumnya terdapat perbedaan. Keimanan terhadap kitab al-Qur'an kita wajib mengamalkannya dan terikat terhadap hukum-hukum yang terkandung didalamnya. Namun keimanan kepada kitabkitab sebelumnya, hanya sekedar menyakininya saja bahwa kitab tersebut pernah ada dan dari Allah Swt, sebagai kitab dan syariat umat terdahulu. Ketika telah datang risalah Islam yang dibawa oleh Nabi Muhammad Saw, dengan mukjizat al-Quran sebagai pedoman kehidupan umat Nabi Muhamad saw, maka umat Nabi Muhammad wajib terikat dengan al-Qur'an dan hadits serta aturan yang terpancar dari keduanya atau aturan-aturan yang digali dari alQuran dan hadits.

c) Dalil Aqli Iman Kepada Nabi Muhammad Saw.

Dalil yang menunjukkan bahwa Muhammad adalah Rasul Allah adalah dalil aqli. Sebab telah terbukti secara aqli bahwa al-Qur'an berasal dari Allah Swt. Nabi Muhammad Saw, adalah orang yang membawa al-Qur'an. Sedangkan al-Qur'an adalah 
Kalamullah dan Syari'at Allah Swt. Padahal, tidak ada yang membawa Kalamullah dan Syari'at Allah kecuali para Nabi dan Rasul.

Al-Qur'an sebagai mukjizat Nabi Muhammad Saw, sampai sekarangpun tetap merupakan mukjizat. Karena telah ditetapkan dengan jalan mutawatir yang merupakan dalil yang qath'i dan yakin bahwa yang membawa alQur'an adalah Nabi Muhammad Saw. Ini merupakan bukti yang pasti dan telah terbukti pula bahwa al-Qur'an adalah syariat Allah dan datang dari Allah. Dengan demikian, hal ini menjadi dalil aqli bahwa Nabi Muhammad Saw, sebagai Nabi dan Rasul Allah Swt. Sedangkan keimanan kepada Nabi-Nabi dan Rasul sebelumnya dibuktikan melalui dalil naqli (An-nabhani, 2003). Sebagaimana dijelaskan dalam al-Qur'an:

"Semuanya beriman kepada Allah, malaikat-malaikatNya, kitab-kitabNya dan rasulrasu-Nya. (mereka mengatakan): "Kami tidak membeda-bedakan antara seseorangpun (dengan yang lain) dari rasul-rasul-Nya". (TQS. al-Baqarah [2]: 285)

"Katakanlah (hai orangorang mukmin): "Kami beriman kepada Allah dan apa yang diturunkan kepada Kami, dan apa yang diturunkan kepada Ibrahim, Isma'il, Ishaq, Ya'qub dan anak cucunya, dan apa yang diberikan kepada Musa dan Isa serta apa yang diberikan kepada nabi-nabi dari Tuhannya. Kami tidak membeda-bedakan seorangpun diantara mereka dan Kami hanya tunduk patuh kepada-Nya". (TQS. al-Baqarah [2] : 136)
Demikianlah dalii-dalil naqli, berkenaan dengan keimanan terhadap rasul-rasul. Dengan demikian keimanan terhadap kerasulan Nabi Muhammad Saw, adalah menyakini bahwa Nabi Muhammad Saw, sebagai Nabi kita dan sekaligus kita sebagai ummatnya harus mengikuti risalah Islam yang beliau bawa dan juga menyakini bahwa beliau adalah sebagai Nabi terakhir atau Nabi penutup. Namun, keimanan terhadap rasul-rasul sebelumnya, kita hanya menyakini bahwa mereka adalah benar sebagai Nabi dan Rasul yang telah di utus oleh Allah Swt, terhadap ummat terdahulu.

2) Menanamkan Akidah Islam dengan Dalil Naqli

Dalil naqli adalah suatu berita yang bersifat pasti (al-khabar alqath'i) yang memberitakan kepada kita tentang rukun-rukun iman (akidah) (Husen, 2006). Adapun rukun-rukun iman (akidah) yang dibuktikan dengan dalil naqli ada tiga yaitu, iman kepada malaikat, iman kepada hari kiamat, dan iman kepada qadha dan qadar.

a) Iman Kepada Malaikat

Keimanan kepada malaikat membutuhkan adanya dalil naqli, karena malaikat bersifat ghoib. Jadi, menanamkan keyakinan adanya malaikat harus dengan dalil-dalil naqli yang bersumber dari al-Qur'an (An-nabhani, 2003), diantaranya dalil-dalil tersebut adalah:

"Allah menyatakan bahwasanya tidak ada Tuhan melainkan Dia (yang berhak disembah), yang menegakkan keadilan. Para Malaikat dan orang-orang yang berilmu (juga 
menyatakan yang demikian itu)". (TQS. Ali 'Imran [3] : 18)

"Sesungguhnya kebajikan itu ialah beriman kepada Allah, hari Kemudian, malaikat-malaikat, kitab-kitab, nabi-nabi dan memberikan harta yang dicintainya kepada kerabatnya, anak-anak yatim, orang-orang miskin, musafir (yang memerlukan pertolongan) dan orang-orang yang meminta-minta; dan (memerdekakan) hamba sahaya, mendirikan shalat, dan menunaikan zakat; dan orangorang yang menepati janjinya apabila ia berjanji, dan orangorang yang sabar dalam kesempitan, penderitaan dan dalam peperangan. mereka Itulah orang-orang yang benar (imannya); dan mereka Itulah orang-orang yang bertakwa.(TQS. al-Baqoroh [2]:18)

"Barangsiapa yang kafir kepada Allah, malaikat-malaikatNya, kitab-kitab-Nya, rasul-rasulNya, dan hari Kemudian, maka sesungguhnya orang itu telah sesat sejauh-jauhnya". (TQS. anNisa [4]: 136)

b) Iman Kepada Hari Kiamat

Iman kepada hari kiamat membutuhkan dalil naqli, karena ia bersifat ghoib. Keimanan kita kepada hari kiamat karena dijelaskan oleh wahyu Allah Swt. Iman terhadap hari kiamat adalah iman terhadap hari kebangkitan, yaitu waktu berakhirnya (seluruh) makhluk yang ada di dunia. Semua yang ada didalamnya mati, kemudian Allah menghidupkan lagi yang mati. Kemudian Allah mengumpulkan tulang belulang mereka yang hancur berserakan. Allah mengembalikan jasad-jasad seperti sediakala dan Allah mengembalikan kepadanya ruhruh (An-nabhani, 2003). Allah berfirman:

"Kemudian, Sesungguhnya kamu sekalian akan dibangkitkan (dari kuburmu) di hari kiamat". (TQS. al-Mukminum [23]: 16)

"Yang demikian itu, karena sesungguhnya Allah, Dialah yang haq dan sesungguhnya Dialah yang menghidupkan segala yang mati dan sesungguhnya Allah Maha Kuasa atas segala sesuatu. Dan sesungguhnya hari kiamat itu pastilah datang. Tak ada keraguan padanya. Dan bahwasanya Allah membangkitkan semua orang di dalam kubur". (TQS. al-Hajj [22]: 6-7)

Termasuk iman terhadap hari kiamat adalah iman bahwa manusia akan diberikan kitabkitab mereka pada hari kiamat. Allah berfirman:

"Dan tiap-tiap manusia itu telah Kami tetapkan amal perbuatannya (sebagaimana tetapnya kalung) pada lehernya. Dan Kami keluarkan baginya pada hari kiamat sebuah kitab yang dijumpainya terbuka. 'Bacalah kitabmu'. (TQS. al-Isra [17] : 13,14)

Orang-orang mukmin diberikan kitabnya disebelah tangan kanan mereka, sedangkan orang-orang kafir diberikan kitabnya disebelah tangan kiri mereka. Allah berfirman:

"Adapun orang yang diberikan kitabnya dari sebelah kanannya, maka dia akan diperiksa dengan pemeriksaan yang mudah, dan dia akan kembali kepada kaumnya (yang 
sama-sama beriman) dengan gembira. Adapun orang yang diberikan kitabnya dari belakang, maka dia akan berteriak: 'Celakalahaku'. Dan dia akan masuk kedalam api yang menyala-nyala (neraka)". (TQS. al-Insyiqaaq [84]: 7-12)

"Adapun orang yang diberikan kepadanya kitabnya dari sebelah kirinya, maka dia berkata: 'Wahai alangkah baiknya kiranyatidak diberikan kepadaku kitabku (ini). Dan aku tidak mengetahui apa hisab terhadap diriku. Wahai kiranya kematian itulah yang menyelesaikan segala sesuatu. Hartaku sekali-kali tidak memberi manfaat kepadaku. Telah hilang kekuasaanku dariku'. (Allah berfirman): 'Peganglah dia lalu belenggulah tangannya ke lehernya'.

Kemudian masukkanlah dia ke dalam api neraka yang menyala-nyala. Kemudian belitlah dia dengan rantai yang panjangnya tujuh puluh hasta". (TQS. al-Haaqah [69] : 25-32)

Juga termasuk iman terhadap hari kiamat adalah iman bahwa surga itu benar dan neraka itu benar. Surga adalah tempat yang diciptakan untuk orang-orang yang beriman. Orang kafir tidak akan bisa untuk memasukinya selamanya. Allah berfirman:

"Dan bersegeralah kamu kepada ampunan dari Tuhanmu dan kepada surga yang luasnya seluas langit dan bumi yang disediakan untuk orang-orang yang bertakwa". (TQS. Ali Imran [3]: 133)

"Dan penghuni neraka
menyeru penghuni surga:
Limpahkanlah kepada kami

sedikit air atau makanan yang telah dirizkikan Allah kepadamu. 'Mereka (penghuni surga) menjawab: 'Sesungguhnya Allah telah mengharamkan keduanya itu atas orang-orang kafir'. (TQS. al-A'raf [7]: 50) "Itulah surga yang akan Kami wariskan kepada hambahamba Kami yang selalu bertakwa". (TQS. Maryam [19]: 63)

Adapun neraka itu adalah tempat yang diciptakan, dimana seorang mukmin tidak akan kekal didalamnya. Allah berfirman:

"Tidak ada yang masuk kedalamnya kecuali orang-orang yang paling celaka, yang mendustakan (kebenaran) dan berpaling (dari iman). Dan kelak akan dijauhkan orang yang paling takwa dari neraka itu". (TQS. alLail [92]: 15-17)

Akan masuk neraka orang yang Allah kehendaki dari golongan kaum Muslim yang lebih banyak dosa besarnya dan kejahatannya dibandingkan dengan dosa kecil dan kebaikankebaikannya. Kemudian mereka dikeluarkan dari neraka dan dimasukkan kedalam surga. Allah berfirman:

"Jika kamu menjauhi dosadosa besar diantara dosa-dosa yang dilarang kamu mengerjakannya, nisacaya Kami hapus kesalahan-kesalahanmu (dosa-dosamu yang kecil) dan Kami masukkan kamu ke tempat yang mulia (surga)". (TQS. anNisa [4]: 31)

"Dan adapun orang-orang yang ringan timbangan (kebaikan) nya, maka tempat kembalinya adalah neraka Hawiyah. Dan tahukah kamu apakah neraka 
Hawiyah itu? (Yaitu) api yang sangat panas". (TQS. al-Qari'ah [101]: 8-11)

Termasuk iman terhadap adanya surga adalah iman bahwa kenikmatan surga itu bisa dirasakan. Dan para penghuni surga makan, minum, berinteraksi, berpakaian, dan bersenang-senang. Allah berfirman:

"Mereka dikelilingi oleh anak-anak muda yang tetap muda, dengan membawa gelas, ceret dan sloki (piala) berisi minuman yang diambil dari air yang mengalir. Mereka tidak pening karenanya dan tidak pula mabuk, dan buah-buahan dari apa yang mereka pilih, dan daging burung dari apa yang mereka inginkan. Dan (di dalam surga itu) ada bidadari-bidadari yang bermata jeli, laksana mutiara yang tersimpan baik, sebagai balasan bagi apa yang telah mereka kerjakan". (TQS. alWaaqi'ah [56]: 17-24)

"Mereka memakai pakaian sutera halus yang hijau dan sutera tebal dan dipakaikan kepada mereka gelang terbuat dari perak, dan Tuhan memberikan kepada mereka minuman yang bersih. (TQS. alInsan [76]: 21)

"Sesungguhnya orangorang yang berbuat kebajikan minum dari gelas (berisi minuman) yang campurannya adalah air kafur, (yaitu) mata air (dalam surga) yang dari padanya hamba-hamba Allah minum, yang mereka dapat mengalirkannya dengan sebaik-baiknya". (TQS. al-Insan [76] : 5-6)

"Dan Dia memberi balasan kepada mereka karena kesabaran mereka (dengan) surga dan (pakaian) sutera, di dalamnya mereka duduk bertelakan di atas dipan, mereka tidak merasakan di dalamnya (teriknya) matahari dan tidak pula dingin yang bersangatan. Dan naungan (naungan pohon-pohon surga itu) dekat diatas mereka dan buahnya dimudahkan memetiknya semudah-mudahnya. Dan diedarkan kepada mereka bejana-bejana dari perak dan piala-piala yang bening laksana kaca, (yaitu) kaca-kaca (yang terbuat) dari perak yang telah diukur mereka dengan sebaikbaiknya". (TQS. al-Insan [76]: 1216)

Dan lain-lain yang tergolong macam-macam kenikmatan yang telah disebutkan oleh al Qur'an secara jelas. Termasuk juga iman dengan (adanya) neraka adalah iman bahwa azabnya dapat dirasakan. Dan para penghuni neraka merasakan berbagai macam azab, keadaan yang sangat dingin, nanah yang mendidih dan lain-lain yang terdapat dalam penjelasan alQur'an, seperti azab (siksaan) dengan rantai dan belenggu, cairan panas, tempat makan yang panas, makanan mereka dari pohon zaqqum dan minuman mereka dari air yang sangat panas lagi mendidih. Allah berfirman:

"Sesungguhnya Kami menyediakan bagi orang-orang yang kafir rantai, belenggu dan neraka yang menyala-nyala. (TQS. al-Insan [76]: 4)

"Sesungguhnya pohon zaqqum itu makanan orang yang banyak berdosa". (TQS. adDukhan [44]: 43-44) 
"Dalam (siksaan) angin yang amat panas dan air yang panas yang mendidih". (TQS. alWaqi'ah [56]: 42)

"Sesungguhnya Kami telah sediakan bagi orang orang zalim itu neraka, yang gejolaknya mengepung mereka. dan jika mereka meminta minum, niscaya mereka akan diberi minum dengan air seperti besi yang mendidih yang menghanguskan muka. Itulah minuman yang paling buruk dan tempat istirahat yang paling jelek. (TQS. al-Kahfi [18]: 29)

"Dan tiada (pula) makanan sedikitpun (baginya) kecuali dari darah dan nanah". (TQS. alHaaqqah [69]: 36)

"Sesungguhnya orangorang yang kafir kepada ayat-ayat Kami, kelak akan Kami masukkan mereka ke dalam neraka. Setiap kali kulit mereka hangus, Kami ganti kulit mereka dengan kulit yang lain, supaya mereka merasakan azab. Sesungguhnya Allah Maha Perkasa lagi Maha Bijaksana. (TQS. an-Nisa [4]: 56)

"Dan orang-orang kafir bagi mereka neraka Jahannam. mereka tidak dibinasakan sehingga mereka mati dan tidak (pula) diringankan dari mereka azabnya. Demikianlah Kami membalas Setiap orang yang sangat kafir. (TQS. Faathir [35] : 36)

'Kemudian sesungguhnya kamu, hai orang yang sesat lagi mendustakan, benar-benar akan memakan pohon zaqqum, dan akan memenuhi perutmu dengannya. Sesudah itu kamu akan meminum air yang sangat panas. Maka kamu minum seperti unta yang sangat haus minum". (TQS. al-Waqi'ah [56]: 51-55)

$$
\text { "Kepada mereka }
$$

dinampakkan neraka pada pagi dan petang". (TQS. al-Mukmin [40]: 46)

Demikianlah dalil-dalil tentang hari kiamat, keimanan terhadap hari kiamat juga akan melahirkan keimanan terhadap hari penghisaban dan surga neraka serta siksa dan keindahan bagi orang-orang yang bertaqwa. Keimanan ini akan melahirkan ketaatan terhadap Allah Swt.

c) Iman Kepada Qadla dan Qadar $\mathrm{Di}$ dalam bahasa terdapat kata qadla, yaqdli, dan qadlaanasysyai, artinya dia telah membuat sesuatu dengan segenap kesempurnaan dan ketentuannya. Wa qadla baina alkhashmaini, artinya telah menghukumi atau memutuskan, maka selesailah suatu perkara (An-nabhani, 2003). Kata qadla terdapat di dalam beberapa ayat al-Qur'an. Allah Swt berfirman:

"Apabila Allah berkehendak menetapkan sesuatu, maka Allah hanya cukup berkata kepadanya: 'Jadilah', lalu jadilah dia”. (TQS. Ali 'Imran [3]: 47)

Maksudnya, apabila suatu perkara telah diputuskan maka perkara tersebut termasuk sesuatu yang tidak dihalanghalangi dan dirintangi. Allah Swt berfirman:

"DialahYang menciptakan kamu dari tanah, sesudah itu ditentukannya ajal (ketentuanmu). (TQS. al-An'am [6]: 2)

Maksudnya, Allah menjadikan makhluk yang telah diciptakan dari tanah berupa ajal (tempo) antara kejadiannya dan kematiannya. Allah Swt berfirman: 
"Dan Tuhanmu telah memerintahkan supaya kamu jangan menyembah selain Dia". (TQS. al-Isra [17]: 23)

Maksudnya, Allah memerintahkan suatu kewajiban (yaitu) agar kalian tidak menyembah selainNya. Allah berfirman:

"Dan tidaklah patut bagi laki-laki yang mukmin dan tidak (pula) bagi perempuan yang mukmin, apabila Allah dan Rasul Nya telah menetapkan suatu ketetapan akan ada bagi mereka pilihan (yang lain) tentang urusan mereka". (TQS. al-Ahzab [33]: 36) Maksudnya,

Allah memerintahkan suatu perkara dan memutuskan suatu hukum. Allah berfirman:

"Maka Dia menjadikannya tujuh langit". (TQS. Fushshilat [41]: 12)

Maksudnya, Allah telah menciptakan langit dengan ketentuan-ketentuan di saat kejadiannya sebanyak tujuh lapis.

Allah Swt berfirman:

"(Allah mempertemukan dua pasukan itu) agar Dia melakukan suatu urusan yang mesti dilaksanakan". (TQS. alAnfal [8]: 42)

Maksudnya untuk menentukan suatu perkara yang keberadaannya wajib dilaksanakan. Allah berfirman:

"Dan

diputuskanlah perkaranya". (TQS. al-Baqarah [2]: 210)

Maksudnya telah selesai suatu perkara, yaitu keruntuhan dan kehancuran mereka kemudian berakhir. Allah berfirman:
"Untuk disempurnakan umur (mu) yang telah ditentukan". (TQS. al-An'am [6]: 60)

Maksudnya, menetapkan ajal yang telah ditentukan dan diputuskan hingga dibangkitkan kematian dan pembalasan terhadap segala perbuatan mereka. Allah berfirman:

"Katakanlah: "kalau sekiranya ada padaku apa (azab) yang kamu minta supaya disegerakan kedatangannya, tentu telah diselesaikan Allah urusan yang ada antara aku dan kamu". (TQS. al-An'am [6]: 58)

Maksudnya, sungguh perkara itu telah berakhir dan Kuhancurkan kalian segera. Allah berfirman:

"Dan hal itu adalah suatu perkara yang sudah diputuskan". (TQS. Maryam [19]: 21)

Maksudnya adalah sebuah perkara dan hukum yang di tetapkan Allah. Perkara tersebut telah ditetapkan keberadaannya, maksudnya adalah memang harus terjadi (dan tidak bisa ditolak) untukmu (Maryam), karena ia termasuk qadla Allah (keputusan Allah Swt). Allah telah berfirman:

"Hal itu bagi Tuhanmu adalah suatu kemestian yang sudah ditetapkan". (TQS. Maryam [19]: 71)

Al-Hatmu asal katanya dari hatama al-amru, artinya suatu perkara yang diwajibkan dengan kewajiban yang pasti dan mengikat. Artinya, kedatangan mereka wajib bagi Allah. Allah mewajibkan atas diriNya dan memutuskannya sendiri. Dengan demikian kata qadla merupakan lafadz musytarakah yang memiliki beberapa pengertian. 
antaranya membuat sesuatu berdasarkan keputusan, menghendaki suatu perkara serta menjadikan sesuatu, menyuruh suatu perintah serta menyempurnakan perintah tersebut, kepastian diwujudkannya suatu perkara serta pastinya perkara tersebut, penyelesaian sebuah perkara serta ketetapan perkara tersebut, dan menetapkan suatu perintah yang pasti dilaksanakan. Dari beberapa pengertian tadi tidak dijumpai bahwa qadla berarti hukum Allah pada perkaraperkara yang bersifat kulliyyat (global) saja. Juga tidak dijumpai pada perkara-perkara parsial (rinciannya). Oleh karena ini maka kata qadla mempunyai beberapa makna bahasa yang telah digunakan al-Qur'an. Dan tidak ada pertentangan mengenai makna-makna tersebut. Maknamakna diatas digunakan menurut lafadz bahasa. Jadi akal tidak turut campur didalamnya (Annabhani, 2003).

Sedangkan qadar menurut bahasa, qadara al-amra wa qaddarahu, yakni mempertimbangkan, maksudnya sesuatu dipertimbangkan atau diukur dengan sesuatu yang lain, lalu jadilah sesuatu tadi berdasarkan pada ukurannya (An-nabhani, 2003). Di dalam alQur'an terdapat kata qadar yang mengandung beberapa arti. Allah berfirman:

"Dan adalah ketetapan Allah itu suatu ketetapan yang pasti Berlaku". (TQS. al-Ahzab [33]: 38)

Maksudnya perkara yang sudah diputuskan tidak bisa dibatalkan lagi dan keputusannya tidak dapat diganggu gugat. Allah berfirman:

"Lalu membatasi rizkinya". (TQS. al-Fajr [89]: 16)

Maka Allah menyempitkan

rizki atasnya. Allah berfirman:

"Maka bertemulah air-air itu untuk satu urusan yang sungguh telah ditetapkan". (TQS. al-Qamar [54]: 12)

Maksudnya adalah terhadap kejadian yang telah Allah tentukan di lauhil mahfuz, yakni telah ditulis oleh Allah di lauhil mahfuz, berupa kehancuran kaum Nabi Nuh as dengan banjir dan air bah. Allah berfirman:

"Dan Dia menentukan padanya kadar makananmakanan (penghuni)nya. (TQS. Fushshilat [41]: 10)

Maksudnya adalah menjadikannya tumbuhan sebagai makanan pokok bagi penduduknya, yaitu khasiat tumbuhan makanan pokok. Allah berfirman:

"Sesungguhnya dia telah memikirkan dan menetapkan (apa yang ditetapkannya). (TQS. alMudatstsir [74]: 18)

Maksudnya, memikirkan apa yang akan ia ucapkan tentang al-Qur'an dan menetapkan dalam dirinya sesuatu yang ia katakan dan yang ia persiapkan. Allah berfirman:

"Yang menciptakan, dan menyempurnakan (penciptaanNya), dan yang menentukan kadar (masing-masing) dan memberi petunjuk. (TQS. al-A'la [87]: 2-3)

Maksudnya, Allah menciptakan segala sesuatu, kemudian menyamaratakannya dan memberikan kepada setiap 
binatang sesuatu yang menjadi manfaat baginya. Lalu memberikan petunjuk kepadanya dan memperkenankan kepadanya cara pemanfaatannya, yaitu menjadikan setiap makhluk hidup seperti manusia dan binatang berupa (adanya) kebutuhan yang menuntut untuk dipenuhi dan menunjukkan kepadanya cara pemuasannya. Firman Allah:

"Dan Dia menentukan
padanya kadar makanan-
makanan (penghuni)nya. (TQS. Fushshilat [41]: 10)

Allah berfirman:

"Dan Kami tetapkan antara negeri-negeri itu (jarak-jarak) perjalanan". (TQS. Saba' [34]: 18)

Maksudnya, Kami jadikan didalamnya kemudahan untuk berjalan dan keamanannya. Allah berfirman:

"Sesungguhnya Allah telah mengadakan ketentuan bagi tiaptiap sesuatu". (TQS. ath-Thalaq [65]: 3)

Maksudnya, ketentuan waktu yang bersifat sementara. Allah berfirman:

"Sesungguhnya Kami menciptakan segala sesuatu menurut ukuran". (TQS. al-Qamar [54]: 49)

Maksudnya, berdasarkan ketentuan. Allah berfirman:

"Sampai waktu yang ditentukan. (TQS. al-Mursalat [77] :22)

Maksudnya, sampai batas waktu yang ditentukan. Allah berfirman:

"Kami telah menentukan kematian di antara kamu". (TQS. al-Waqi'ah [56]: 60)

Maksudnya, Kami jadikan batasan kematian di antara kalian berbeda-beda, usia kalian berbeda-beda. Ada yang berusia pendek, panjang dan sedang. Allah berfirman:

"Dan Kami tidak menurunkannya melainkan dengan ukuran tertentu". (TQS. al-Hijir [15]: 21)

Maksudnya, dengan ukuran tertentu. Allah berfirman:

"Kami telah menentukan bahwa sesungguhnya ia itu termasuk orang-orang yang tertinggal (bersama-sama dengan orang kafir lainnya)". (TQS. alHijir [15]: 60)

Maksudnya, merupakan ketentuan Kami bahwa istrinya (Nabi Luth) termasuk orang-orang yang tertinggal bersama dengan orang-orang kafir. Allah berfirman:

"Kemudian kamu datang menurut waktu yang ditetapkan hai Musa". (TQS. Thaha [20]: 40)

Maksudnya, engkau datang pada waktu tertentu terhadap hal itu. Apa yang telah ditentukan Allah di lauhul mahfuz, yaitu sesuatu yang telah ditentukan dan diketahuinya. Itu termasuk di dalam firman Allah Swt:

"Untuk satu urusan yang sungguh telah ditetapkan. (TQS. al-Qamar [54]: 12)

Qadar adalah ketentuan Allah dan ilmu-Nya. Dengan kata lain segala sesuatu bersandar pada ketentuan dan kemahatahuan Allah. Artinya, Allah telah menetapkannya di lauhul mahfuz (An-nabhani, 2003).

Demikianlah pembahasan berkenaan dengan metode menanamkan aqidah Islam terhadap seseorang melalui proses berfikir dan disertai dengan dalil-dalil aqli maupun dalil-dalil naqli. Sehingga 
melahirkan keimanan dan keyakinan yang bersifat pasti. Dengan metode penanaman akidah seperti ini, maka akan melahirkan keimanan pada diri seseorang sehingga memiliki keimanan yang kuat yang akan dijadikan pondasi dan landasan dalam pemikirannya, dalam mengatasi permasalahan kehidupannya dan dalam membangun setiap perbuatannya yang timbul dari kebutuhan jasmanidan naluri. Maka akan muncullah pribadi yang kokoh keimanannya.

Disini perlu penulis tegaskan pandangan Syaikh Taqiyuddin an-Nabhani terhadap akidah ahli kalam (mutakallimin). $\mathrm{Hal}$ ini dalam rangka untuk menjelaskan bahwa pandangan Syaikh Taqiyuddin an-Nabhani terkait dengan pemahamannya bahwa keimanan harus dibangun dengan akal berbeda dengan pemahaman ahli kalam (mutakallimin) dalam membangun pemikiran akidahnya. Syaikh Taqiyuddin an-Nabhani dalam kitabnya, Asy-Syakhshiyah alIslamiyah, menjelaskan, para ahli kalam beriman terhadap Allah dan Rasul-Nya. Juga beriman dengan apa yang dibawa oleh Rasul-Nya. Dengan asas tersebut mereka berargumentasi dengan dalil-dalil aqli yang bersifat mantiqi (ilmu logika) (An-nabhani, 2003). Mereka mulai membahas tentang baharunya alam (huduts al-'alam) dan membuat dalil atas baharunya segala sesuatu. Lalu hal itu semakin meluas sehingga muncul topik topik baru dihadapan mereka, dan merekapun membahasnya.
Para ahli mutakallimin membahas cabang-cabang dari perkara tersebut hingga akhir dari proses mantiq. Mereka membahas ayat-ayat bukan untuk dipahami sebagaimana metode pendahulu mereka, dan sebagaimana tujuan dari alQur'an, yang mereka lakukan adalah mengimaninya, lalu membuat argumentasi terhadap ayat tersebut (berdasarkan buktibukti) tentang apa yang mereka pahami. Ini merupakan salah satu aspek pembahasan. Dalam aspek pembahasan lainnya, yaitu pandangannya terhadap ayatayat mutasyabihat para ahli kalam tidak merasa puas dengan keimanannya terhadap ayat-ayat mutasyabihat secara global tanpa adanya rincian. Setelah mengkaji ayat-ayat tersebut secara keseluruhan, mereka mengumpulkan ayat-ayat yang secara dzahir terdapat kontradiksi di dalamnya, seperti al-jabr dan al-ikhtiar, juga ayat-ayat yang di dalamnya tampak jismiyatullah (bentuk jasad Allah).

Akal telah mendominasi mereka dalam memahami ayatayat tersebut. Mereka bersikap lancang terhadap sesuatu di mana orang-orang selain mereka tidak akan berbuat lancang seperti itu. Mereka membawa setiap perkara kepada ar-ra'yu (rasio). Apabila mereka telah sampai kepada ra'yunya tadi mereka bersandar kepada ayatayat yang menurut pendapat mereka kontradiktif, maka mereka melakukan ta'wil. Ta'wil adalah ciri pertama yang sangat tampak pada ahli kalam (mutakallmin). Jika suatu pembahasan mengarah pada bahwa Allah tidak 
terikat (bebas) dengan arah dan tempat, maka mereka menta'wilkan ayat-ayat tersebut seraya mengisyaratkan bahwa Allah Swt berada diatas langit. Mereka juga menta'wil al-istiwa' 'ala al-arsy dengan bersemayamnya Allah diatas kursi arsy. Kemudian jika suatu pembahasan mengarah kepada penafian (peniadaan) arah bagi Allah dan mata manusia tidak mungkin melihatNya, maka mereka menta'wilkan pemberitahuan (al-ikhbar) dengan menyatakan bahwa manusia melihat Allah. Demikianlah ta'wil merupakan salah satu alat ahli kalam (mutakallimin) dan menjadi ciri khas paling mencolok yang membedakan mereka dari para pendahulunya (ulama sebelumnya).

Metode pembahasan ini memberikan kepada akal kebebasan untuk membahas segala sesuatu, baik hal itu bisa dijangkau maupun tidak, baik itu menyangkut alam maupun metafisika, baik yang dapat diindera maupun yang tidak dapat diindera. Dapat dipastikan bahwa mereka menjadikan akal sebagai asas terhadap al-Qur'an, bukan menjadikan al-Qur'an sebagai asas bagi akal. Jika pada sisi pena'wilan ini terdapat petunjuk, maka dengan sendirinya mereka menuju kearah (tanda) mana pun yang mereka anggap bahwa akal mampu melihatnya (An-nabhani, 2003).

Dari pemaparan tentang metode mutakallimin diatas, jelas bahwa metode itu tidak benar. Disamping itu, metode yang mereka tempuh tidak membawa kepada keimanan dan juga tidak menguatkan iman. Bahkan metode yang mereka tempuh tidak memicu pada terwujudnya pemikiran dan tidak pula menguatkannya. Metode yang mereka lakukan hanya akan memberikan pengetahuan saja sebatas informasi, sedangkan pengetahuan itu bukan iman dan juga bukan pemikiran. Dengan demikian, kesalahan metode ahli kalam (mutakallimin) ini tampak dalam beberapa aspek, yaitu:

I. Dalam berargumentasi metode ini bersandar kepada asas mantiq (logika) bukan bersandar pada indrawi. Ini memiliki dua kesalahan:

i. Mengharuskan seorang muslim untuk mempelajari ilmu mantiq agar mampu mendatangkan bukti akan adanya Allah (An-nabhani, 2003). Berarti orang yang tidak mengetahui mantiq tidak mampu berargumen untuk menunjukkan kebenaran akidahnya. Jadi, ilmu mantiq dinisbahkan dengan ilmu kalam sebagaimana layaknya ilmu nahwu yang dinisbahkan (disyaratkan) untuk membaca bahasa Arab (apalagi) setelah rusaknya bahasa. Padahal ilmu mantiq tidak ada hubungannya dengan akidah Islam dan tidak ada urusannya dengan argumentasi. Islam telah datang sementara saat itu kaum Muslim tidak mengenal ilmu mantiq. Mereka mengemban risalah Islam dan mengajukan dalildalil yang pasti berdasarkan akidah mereka, dan mereka tidak memerlukan sedikitpun ilmu mantinq. Hal ini menunjukkan posisi ilmu mantiq tidak termasuk dalam cakupan tsaqafah Islam. IImu mantiq tidak dibutuhkan sedikit pun dalam argumentasi terhadap akidah Islam.

ii. Penggunaan asas mantiq memiliki peluang untuk salah. 
Berbeda dengan asas yang
sifatnya indrawi, yang
memastikan adanya sesuatu tanpa terjadi kesalahan sama sekali. Sesuatu yang memiliki kemungkinkan adanya kesalahan tidak sah dijadikan asas dalam beriman. Mantiq berpeluang menghasilkan kekeliruan dan memungkinkan hasil akhirnya tidak benar. Sebab, walaupun disyaratkan premispremisnya itu benar begitu pula susunannya, akan tetapi dengan membangun premis diatas premis berarti menjadikan benarnya kesimpulan didasarkan pada benarnya premis-premis tadi. Sementara benarnya premis tidak bisa dijamin karena kesimpulan tidak disandarkan secara langsung kepada indera (kenyataan empirik) melainkan disandarkan kepada penggabungan premispremis satu dengan yang lainnya. Maka kesimpulannya tidak bisa dijamin kebenarannya. Itu karena yang dihasilkan merupakan penggabungan antara premis yang satu dengan premis lainnya berlangsung mengikuti (runutan) sistematika rasio diatas rasio, kemudian dihasilkan kesimpulan yang rasional pula. Adapula penggabungan dua premis yang berlangsung mengikuti runutan sistematika penginderaan diatas penginderaan, kemudian dihasilkan kesimpulan yang sesuai dengan (kenyataan) empirik. Sistematika rasio di atas rasio menjerumuskan pada kesalahan dan akan terjadi kesimpangsiuran pada kesimpulannya. Juga akan terjadi elaborasi (pemanjanglebaran) dalam setiap rangkaian premis. Kesimpulan-kesimpulan yang rasional itu terjadi berdasarkan aspek pengandaian dan perkiraan, bukan berdasarkan kenyataan empirik, sehingga ujung perjalanan dari kebanyakan premis-premis ini selalu bercampur baur dan kacau. Berdasarkan hal ini pengambilan dalil melalui premis-premis yang berlangsung mengikuti runutan sistematika rasio diatas rasio berpeluang tergelincir dalam kesalahan. Contohnya, dikatakan oleh para ahli mantiq- bahwa alQuran itu adalah kalam Allah yang wujudnya tersusun dari huruf-huruf yang sistematis dan berkesinambungan (sebagai premis pertama-pen). Dan setiap kalam yang wujudnya tersusun dari huruf-huruf yang sistematis dan berkesinambungan itu adalah baharu (hadits) sebagai premis keduapen-. Maka kesimpulannya adalah bahwa al-Qur'an itu baharu (hadits) dan makhluk. Susunan dari premis-premis ini telah menghasilkan kesimpulan yang berada di luar kesempatan empirik. Karena itu (metode ini) tidak memberikan jalan bagi akal untuk membahasnya atau menentukan hukum atasnya. Artinya, penentuan hukumnya didasarkan pada dugaan atau perkiraan, bukan realita. Terlebih lagi hal itu termasuk dalam perkara-perkara yang akal manusia dilarang untuk membahasnya. Karena, membahas tentang sifat Allah sama dengan membahas DzatNya, padahal dengan cara apapun tidak boleh membahas tentang Dzat Allah. Meskipun demikian, cara mantiq seperti ini memungkinkan juga kita sampai pada kesimpulan yang 
bertentangan dengan kesimpulan sebelumnya. Contohnya, bahwa al-Qur'an itu adalah kalam Allah dan itu merupakan sifat bagi-Nya (sebagai premis pertama). Segala hal yang merupakan sifat Allah itu adalah qadim (terdahulu/kekal) sebagai premis kedua-pen-. Maka kesimpulannya adalah bahwa alQur'an itu qadim (terdahulu/kekal), bukan makhluk. Sangat jelas terdapat kontradiksi di dalam mantiq pada topik permasalahan yang sama. Demikian pula di dalam banyak hal yang mengikuti runutan sistematika logika rasio di atas rasio akan menghasilkan kesimpulan-kesimpulan yang kontradiktif dan sangat aneh.

II. Mutakallimin telah membahas (berbagai perkara) di luar dari fakta yang bisa diindera (Annabhani, 2003). Mereka melampaui batas perkara-perkara yang tidak bisa diindera. Mereka membahas sesuatu yang berada diluar alam (metafisika), seperti Dzat Allah, sifat-sifatNya, sesuatu yang tidak bisa diindera. Mereka mencampuradukkannya hal itu dengan pembahasanpembahasan perkara yang bisa diindera. Mereka telah bersikap berlebihan dalam menganalogkan perkara ghaib (yang tidak dapat diindera) terhadap perkara syahid (yang dapat diindera). Adapun yang dimaksud di sini adalah menganalogkan Allah dengan manusia. Mereka mewajibkan atas Allah sifat adil seperti yang dibayangkan oleh manusia di dunia, mengharuskan Allah untuk melakukan perbuatan baik (shalah) bahkan sebagian mereka mewajibkan kepada Allah untuk melakukan sesuatu yang paling baik (ashlah), karena Allah bersifat Hakim (Maha Bijaksana), tidak melakukan suatu perbuatan kecuali karena suatu tujuan atau hikmah. Perbuatan yang tidak memiliki tujuan adalah kebodohan dan sia-sia. Sedangkan orang yang bijaksana adalah yang memberi kebaikan (manfaat) kepadanya atau kepada orang lain. Karena Allah itu terbebas (Maha Suci) dari mengambil manfaat (untuk diri-Nya), maka berarti Dia melakukan suatu perbuatan agar orang lain dapat mengambil manfaatnya. Inilah yang menyebabkan mereka berkutat membahas perkara yang tidak bisa diindera dan tidak mungkin bisa ditentukan hukumnya melalui proses akal. Mereka terperosok di dalam perkara tersebut. Mereka lengah bahwa perkara yang bisa diindera itu dapat dijangkau, sedangkan Dzat Allah tidak bisa dijangkau. Karena itu tidak bisa dianalogkan salah satu diantara keduanya terhadap yang lainnya. Mereka lupa bahwa tidak benar keadilan Allah dianalogkan dengan keadilan manusia. Juga tidak boleh Allah tunduk terhadap peraturanperaturan alam ini, sementara Dia yang menciptakan alam ini. Allah-lah yang mengaturnya sesuai dengan ketentuan-ketentuan yang telah diciptakanNya. Kita melihat bahwa manusia itu tatkala visi (pandangan)nya sempit maka dia akan memahami keadilan sesuai dengan pemahamannya yang sempit dan menghukumi sesuatu secara khas. Namun, jika pandangannya luas maka pandangannya tentang keadilan pun berubah dan penentuan 
hukum atasnya juga berubah. Lalu bagaimana kita menganalogkan Rabbul'alamin yang IImuNya meliputi segala sesuatu dan kita memberikan (makna tentang) keadilan-Nya sesuai dengan makna keadilan yang kita lihat? Adapun shalah wa alashlah (baik dan terbaik) itu muncul dari cabang perspektif mereka tentang keadilan. Apa yang dikatakan oleh mereka tentang keadilan, dikatakan juga dalam perkara shalah wa alashlah. Orang yang mengamati perkara ini mendapati bahwa manusia itu melihat sesuatu yang didalamnya terdapat kebaikan, apabila visinya meluas maka pandangannya (tentang kebaikan/shalah) juga berbeda.

III. Bahwa metode mutakallimin telah menjadikan akal sebagai dasar (asas) untuk membahas persoalan apapun tentang keimanan. Sebagai konsekuensinya, mereka menjadikan akal sebagai asas bagi al-Qur'an, bukan menjadikan al-Qur'an sebagai asas bagi akal (An-nabhani, 2003). Mereka telah membangun penafsiran terhadap al-Quran sesuai dengan prinsip tersebut yang bersandar pada asas-asas mereka, seperti pensucian mutlak (tanzih), kebebasan berkehendak, keadilan, melakukan yang terbaik (al-ashlah) dan lain-lain. Mereka jadikan akal sebagai hakim (penentu) terhadap ayat-ayat yang 'tampak' kontradiktif dan menjadikannya sebagai ukuran di antara ayat-ayat yang mutasyabihat serta menta'wil ayat-ayat yang tidak sesuai dengan pendapat yang mereka anut, sehingga jadilah ta'wil sebagai metode bagi mereka, tidak ada bedanya baik itu mu'tazilah, ahli sunnah maupun jabariyah. Karena dasarnya bukanlah ayat melainkan akal. Ayat harus dita'wil agar sesuai dengan akal. Begitulah jika akal dijadikan sebagai asas bagi alQuran, yang berakibat pada kesalahan dalam pembahasan, dan kesalahan terhadap perkaraperkara yang dibahas. Seandainya mereka menjadikan al-Qur'an sebagai asas dalam pembahasan dan akal bertumpu pada al-Qur'an, maka mereka tidak akan tertimpa apa yang telah menimpa mereka.

Memang benar, iman bahwa al-Quran itu kalamullah dibangun berlandaskan akal. Akan tetapi setelah diimani, alQuran itu sendiri menjadi asas untuk mengimani apa pun yang dibawanya, bukan lagi akal. Karena itu jika terdapat ayat-ayat al-Qur'an, akal tidak berhak memutuskan benar atau tidak maknanya. Yang berhak memutuskan (benar atau tidak maknanya-pen) adalah ayat-ayat itu sendiri. Akal dalam hal ini fungsinya sebatas memahami saja. Sayangnya mutakallimin tidak melakukan hal itu. Mereka jadikan akal sebagai asas bagi alQur'an. Akibatnya terjadi penta'wilan terhadap ayat-ayat alQur'an.

IV. Bahwa mutakallimin menjadikan pertentangan para filosof sebagai asas dalam pembahasan mereka. Mu'tazilah mengambil (pendapat) dari para filosof dan mereka mengkritiknya. Ahlu sunnah dan jabariyah mengkritik mu'tazilah, dan mereka mengambil (pendapat) dari para filosof 
seraya mengkritiknya. Padahal topik pembahasannya adalah tentang Islam, bukan tentang perselisihan, baik dengan para filosof maupun dengan yang lainnya. Seharusnya mereka membahas topik tentang Islam atau membahas apa yang dibawa oleh al-Qur'an maupun yang terdapat dalam hadits. Lalu berhenti pada batas-batasnya maupun batasan pembahasannya tanpa melihat lagi siapapun orangnya. Namun mereka tidak melakukannya. Mereka telah mengalihkan penyampaian Islam dan penjelasan tentang akidahnya menjadi topik diskusi (yang bersifat teori) dan polemik. Mereka telah mengeluarkan (memisahkan) akidah sebagai kekuatan yang mampu mendorong jiwa dari gelora akidah dan kejelasannya, menjadi sebuah topik yang bersifat debat kusir dan polemik.

Dari pemaparan dia atas, tentang pandangan Syaikh Taqiyuddin an-Nabhani dan pandangan ilmu kalam (mutakallimin) tentang akidah Islam, sangat bertolak belakang. Dengan demikian, Syaikh Taqiyuddin anNabhani bukan bagian dari aliran ilmu kalam (mutakallimin), bahkan beliau menolak dan mengkritisi pandangan ilmu kalam (mutakallimin) dalam pemikiran akidahnya. Menurut pandangan penulis, konsep Syaikh Taqiyuddin an-Nabhani dalam penanaman akidah Islam melalui proses berfikir, inilah konsep yang benar sesuai dengan al-Qur'an dan hadits yang tidak keluar dari aturan hukum syara'. Sementara konsep pemikiran ilmu kalam (mutakallilim) dalam memahami akidah dan proses berfikir terlalu kebablasan, sehingga menyebabkan terjadinya kesalahankesalahan dalam metode mutakallimin. Letak kesalahannya menggunakan akal untuk memikirkan hal-hal ghoib diluar jangkauan akal manuasia tanpa terikat dengan al-Qur'an. Sehingga lebih kepada khayalan dan imajinasi akal. Dengan demikian, untuk mendapatkan akidah yang benar harus kembali kepada metodologi alQur'an.

\section{b. Metode Menanamkan Tsaqofah Islam}

Definisi tsaqofah menurut bahasa berasal dari kata tsaqifa tsaqafataan, artinya menjadi mahir atau piawai. Pelakunya disebut tsaqifun. Kemudian disebut tsaqafa al-kalaama tsaqafatan, artinya dia mahir dan memahami perkataanya. Sedangkan tsaqofah Islam adalah pengetahuan-pengetahuan yang menjadikan aqidah Islam sebagai sebab dalam pembahasannya (Annabhani, 2003). Pengetahuan tersebut bisa mengandung aqidah Islam dan membahas tentang aqidah, seperti ilmu tauhid. Bisa juga pengetahuan yang bertumpu kepada aqidah Islam, seperti fiqih, tafsir dan hadits. Termasuk ilmu pengetahuan yang terkait dengan pemahaman yang terpancar dari aqidah Islam berupa hukum-hukum, ilmu-ilmu bahasa Arab, musthalah hadits, ilmu ushul, ekonomi Islam, politik Islam dan pendidikan Islam. Semuanya termasuk tsaqafah Islam, karena aqidah Islam menjadi sebab dalam pembahasannya.

Tsaqafah Islam seluruhnya berdasarkan kepada al-Qur'an dan Sunnah, dan dari al-Qur'an dan Sunnah. Dari keduanya muncul seluruh cabang tsaqafah Islam. Keduanya termasuk juga dalam 
tsaqafah Islam, karena aqidah Islam mengharuskan mengambil keduanya, dan terikat dengan apa yang dibawa oleh keduanya. AlQur'an telah turun kepada Rasulullah Saw, agar Beliau menjelaskannya kepada manusia. Allah Swt berfirman:

"Dan Kami turunkan kepadamu al-Quran, agar kamu menerangkan kepada umat manusia". (TQS. anNahl [16]: 44)

Al-Quran menyuruh kaum Muslim agar mereka mengambil apa yang telah dibawa oleh Rasul. Allah Swt berfirman:

"Apa yang diberikan Rasul kepadamu maka terimalah dia. Dan apa yang dilarangnya bagimu maka tinggalkanlah". (TQS. al-Hasyr [59] : 7)

Mengambil apa yang dibawa oleh Rasul tidak mungkin kecuali setelah memahami dan mempelajarinya. Akibat dari hal itu adalah adanya pengetahuanpengetahuan yang diharuskan untuk memahami al-Quran dan Sunnah, sehingga muncul berbagai macam pengetahuan Islam. Maka jadilah tsaqafah Islam memiliki madlul tertentu, yaitu al-Quran, Sunnah, bahasa, sharaf, nahwu, balaghah, tafsir, hadits, mushthalah hadits, ushul, tauhid, ekonomi, politik, pendidikan dan lain-lain yang termasuk dalam pengetahuanpengetahuan Islam (An-nabhani, 2003).

Metode menanamkan tsaqofah Islam agar tertanam dalam diri manusia dan menjadi landasan berfikir serta sekaligus dapat membangun pemikiran dan perbuatan pada seseorang sehingga terbentuk kepribadian islami. Maka tsaqofah Islam harus dipelajari dengan metode sebagai berikut (Annabhani, 2003):

1) Tsaqofah Islam dipelajari dengan mendalam hingga dipahami hakekatnya dengan pemahaman yang benar, karena tsaqafah Islam bersifat fikriyah, mendalam, mengakar, dan memerlukan kesabaran dan keteguhan dalam mempelajarinya. Bertsaqafah dengan tsaqafah tersebut merupakan aktivitas berpikir yang membutuhkan pengerahan seluruh upaya (pemikiran) untuk memahaminya. Hal itu memerlukan pemahaman yang menyeluruh, dan membutuhkan pemahaman tentang faktanya serta kaitannya dengan berbagai informasi yang dapat memberikan pemahaman terhadap fakta tersebut. Karena itu penerimaannya harus dengan cara talaqqiyan fikriyan (pemikiran yang disampaikan melalui perjumpaan). Misalnya, setiap muslim wajib mengambil aqidahnya melalui proses berfikir, bukan dengan sekadar menerima begitu saja melalui warisan orang tua. Dengan demikian mempelajari setiap perkara yang berhubungan dengan asas aqidah harus dengan aktivitas berpikir. Begitu pula dengan hukum-hukum syara' yang diseru oleh al-Qur'an dan hadits. Untuk istinbath harus melalui aktivitas berpikir. Dengan aktivitas berpikir dapat dipahami realita/fakta suatu masalah, nash yang berhubungan dengannya, serta penerapan nash tersebut terhadap masalah tadi. Ini semua melalui aktivitas berpikir. Bahkan orang yang 'aami (awam), yang (ingin) mengambil suatu hukum tanpa harus mengetahui dalilnya pun 
memerlukan pemahaman tentang masalahnya, dan pemahaman tentang hukum yang ada untuk menyelesaikan masalah tersebut, agar dia tidak mengambil hukum untuk masalah lain yang bukan untuk masalahnya. Maka harus dilakukan dengan berfikir. Berdasarkan hal ini, maka bertsaqafah dengan tsaqafah Islam, baik itu mujtahid ataupun 'aami penerimaannya harus melalui talaqqiyan fikriyyan, dan tidak mungkin mengambil hukumnya kecuali dengan aktivitas berpikir dan pengerahan seluruh upaya (An-nabhani, 2003).

2) Orang yang sedang mempelajari tsaqofah Islam mesti meyakini apa yang sedang dipelajarinya agar membentuk prilakunya dan menjadi aktivitasnya, yaitu membenarkan hakekat yang dipelajarinya dengan pembenaran yang pasti tanpa ada keraguan jika hakekat yang dipelajari itu berkaitan dengan aqidah, dan berdasarkan ghalabatu adz-dzan (dugaan kuat) kesesuaiannya dengan fakta jika hakekat yang dipelajari itu bukan termasuk perkara aqidah, seperti hukum dan adab. Namun, hakekat itu harus bersandarkan kepada asal yang diyakini dengan keyakinan yang pasti, yang tidak mengandung keraguan. Walhasil, disyaratkan bagi yang belajar untuk mengambil sesuatu yang dipelajarinya dengan penuh keyakinan, baik terhadap apa yang diambilnya maupun pokok pangkal dari sesuatu yang diambilnya. Sama sekali tidak boleh mengambil tsaqafah berdasarkan perkara (asas) lain. Implikasi dari menjadikan keyakinan sebagai asas dalam pengambilan tsaqafah adalah mewujudkan tsaqafah Islam pada kondisi yang paling unggul dan unik. Tsaqafah Islam itu amat mendalam. Pada saat bersamaan ia dapat membangkitkan dan mempengaruhi. Mampu mewujudkan orang yang memiliki tsaqafah tersebut potensi yang bergelora yang mengobarkan api untuk membakar kerusakan dan menyalakan cahaya untuk menerangi jalan kebaikan.

Pembenaran yang pasti terhadap pemikiran-pemikiran tersebut menjalin ikatan yang berjalan secara alami dalam diri manusia antara fakta dengan persepsi yang ada pada dirinya mengenai sesuatu, dikaitkan dengan pemikiran-pemikiran ini, yang dianggap sebagai makna-makna tentang kehidupan, sehingga mendorongnya dengan penuh kerinduan dan semangat untuk mengamalkan pemikiran-pemikiran ini. Dengan demikian tsaqafah Islam memiliki pengaruh yang amat besar di dalam jiwa, sebab ia mampu menggerakkan perasaan terhadap fakta yang ada pada pemikiran. Meyakini tsaqafah Islam merupakan pengikat perasaannya dengan persepsinya sehingga mampu memunculkan dorongan sesuai tsaqofah yang diyakini (An-nabhani, 2003).

3) Tsaqofah Islam dipelajari sebagai pelajaran yang bersifat praktis, sebagai solusi atas fakta yang bisa dijangkau dan diindra, bukan pelajaran yang mengacu pada aspek teoritis, sehingga sesuatu itu disifati berdasarkan hakekatnya untuk memecahkan masalah dan merubahnya. Maka ia akan mengambil hakekat 
(tentang kenyataan) yang ada di alam semesta, manusia dan kehidupan, yang berada dalam jangkauannya atau yang bisa dijangkau oleh panca indranya. Lalu dipelajari dalam rangka untuk memecahkannya serta memberikan hukum ketetapan pada realita tersebut sehingga penentuan sikapnya terhadap hal tersebut sudah jelas, apakah diambil, ditinggalkan atau boleh memilih antara diambil dan tidak. Karena itu Islam tidak menjadikan seseorang mengikuti pengandaian yang bersifat teoritis. Misalnya, di planet Mars mungkin terdapat kehidupan lalu bagaimana orang yang berpuasa di bulan Ramadhan disana, sementara disana tidak terdapat bulan Ramadhan. Sesungguhnya hanya manusia yang hidup di planet bumi ini dijadikan sebagai obyek yang diseru, sehingga dia harus menyaksikan bulan Ramadhan, dan harus berpuasa. Berdasarkan hal ini dalam mempelajari tsaqafah disyaratkan bersifat realistis (ada faktanya) bukan bersifat khayalan, juga bukan bersifat teoristis. Ini agar tsaqafah itu dipelajari benarbenar untuk diterapkan ketika muncul faktanya dalam kehidupan, bukan sekedar untuk mengetahui keindahan tsaqafah dan kepuasan intelektual. Inilah metode Islam dalam mempelajari tsaqofah Islam, yaitu mendalam dalam pembahasan, meyakini sesuatu yang dicapai melalui pembahasan tersebut atau terhadap apa yang dibahas, serta mengambilnya secara praktis untuk diterapkannya dalam kancah kehidupan.

Ketika metode ini dijalankan
dalam proses pembelajaran
tsaqofah Islam, maka seorang
muslim yang memiliki tsaqafah Islam
berdasarkan metode tersebut akan
mendalam pemikirannya, peka
perasaannya dan mampu
memecahkan segala problematika
kehidupan. Metode ini mampu
menjadikan seorang muslim memiliki
kepribadian Islami. Seseorang yang
telah menyakini tsaqofah Islam tidak
dapat dibelokkan kepada tsaqofah
lain, karena pemikiran-pemikiran
Islam yang diperolehnya dalam
tsaqofah dapat
membangkitkan diam dan dapat
mempengaruhi perbuatannya,
bersifat realistis, benar serta bisa menjadi solusi. Lebih dari itu pemikiran-pemikiran Islam ini bisa menjadikan orang yang memiliki tsaqafahnya mempunyai semangat yang menyala-nyala, menjadikan seorang muslim memiliki kemampuan yang luar biasa dalam menghadapi seluruh problematika kehidupan dengan solusi-solusi detailnya, cermat, mudah maupun sulit. Pada dirinya terbentuk 'aqliyah (pola pikir) yang memuaskan akal dan menentramkan jiwa. Terbentuk pula dalam dirinya nafsiyah Islamiyah (pola sikap yang Islam) yang dipenuhi dengan keimanan yang sempurna. Dengan aqliyah dan nafsiyah Islamiyah inilah seseorang akan memiliki kepribadian Islami.

Berdasarkan aqliyah dan nafsiyah Islamiyah ini pula seseorang mampu mengalahkan semua hambatan yang menghadang diperjalanannya. Hal ini akan tercapai jika ia memperhatikan materi tsaqafah Islam yang berupa pemikiran-pemikiran yang mendalam dan cemerlang. Pemikiran-pemikiran tersebut dibangun berdasarkan 
aqidah yang tercermin di dalamnya kesadaran seseorang akan hubungannya kepada Allah Swt. Pemkiran-pemikiran tersebut langsung berasal dari Allah Swt, atau diistinbath dari sesuatu yang berasal dari Allah Swt, yaitu berupa al-Qur'an atau Sunnah. Di dalam pemikiran-pemikiran itu benar-benar terdapat aspek pemikiran (yang memiliki realita), juga terdapat ruh dari segi kesadaran akan hubungannya dengan Allah pada saat bersentuhan dengan pemikiran tersebut, karena dia dari Allah Swt. Pemikiran-pemikiran Islam menjadikan setiap orang yang memiliki tsaqafahnya berpikiran mendalam, cemerlang, memiliki semangat yang menggebu-gebu dan berkobar-kobar, menggadaikan jiwanya karena Allah di jalan Islam dengan mengharapkan keridhaan Allah Swt. Inilah peran tsaqofah Islam dalam proses pembentukan kepribadian islami pada diri seseorang, sehingga dengan tsaqofah Islam inilah pemahaman seseorang terbentuk.

\section{c. Membangun Aqliyah dan Nafsiyah dengan Akidah Islam}

Setelah menanamkan aqidah Islam dan tsaqofah Islam, metode selanjutnya adalah membangun aqliyah dan nafsiyah agar senantiasa terikat dengan akidah Islam dan tsaqofah Islam. Hal ini dilakukan dengan cara mengarahkan kecendrungan atau dorongan naluri dan kebutuhan jasmaninya dalam pemenuhannya senantiasa terikat dengan akidah Islam. Kemudian senantiasa meningkatkan kekuatan ikatan yang mengikat dorongan naluri dan kebutuhan jasmaninya dengan mafhûm yang diperoleh dari aqliyah Islam-nya. Oleh karena itu, untuk meningkatkan nafsiyah seorang muslim harus hidup dalam suasana keimanan, dan bergaul dengan orang-orang soleh, memilih teman yang baik, serta menjauhi orangorang yang berbuat maksiat. Inilah yang disabdakan oleh Rasulullah Saw.

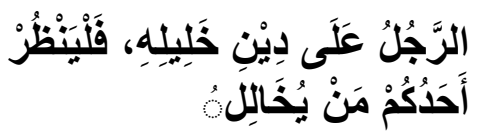

"Seseorang tergantung agama teman dekatnya, maka hendaknya kalian memerhatikan siapakah teman dekatnya"(HR. Abu Daud) Membangun nafsiyah Islamiyah juga dapat dilakukan dengan cara menciptakan sendiri suasana keimanan, dengan memperbanyak amalan-amalan sunnah, atau melakukan aktivitas yang dapat meningkatkan kualitas nafsiyahnya, seperti membaca ayatayat al-Qur'an, menghayati keindahan ciptaan Allah dalam rangka meningkatkan kekuatan spiritualnya, mengkaji dan menghayati perjalanan hidup Rasulullah dan para sahabat dengan tujuan untuk meneladani teladan yang mulia tersebut, khusyû' dalam shalat dengan menghadirkan seluruh makna lafadz dan pemikiran yang dibacanya sehingga kesadaran spiritualnya meningkat, qiyâmul-lail dan berdo'a untuk menguatkan kekuatan spiritualnya, dan selalu menghitung aktivitasnya dengan kesadaran, bahwa setiap amal yang dilakukannya adalah semata-mata untuk dirinya sendiri, bukan untuk orang lain, dengan memahami firman Allah Swt.

"Siapa saja yang melakukan kebaikan, meskipun hanya seberat zarrahpun, pasti dia akan melihatnya. Dan siapa saja yang melakukan keburukan, meskipun 
hanya seberat biji zarrahpun, juga pasti akan melihatnya." (QS. AlZalzalah: 7-8).

Pengertian "dia akan melihatnya" adalah "dia sendiri akan menerima balasannya di akhirat" dan bukan orang lain. Dengan cara seperti ini, seseorang akan senantiasa melakukan keta'atan dan meninggalkan kemaksiatan. Karena membayangan nikmat, azab, surga dan neraka di akhirat. Disamping itu juga pemahaman seperti ini akan mampu mendorong seseorang untuk senantiasa memenuhi semua kebutuhannya baik kebutuhan naluri maupun kebutuhan jasmani sesuai dengan aturan Allah Swt. Karena dia yakin terhadap balasan akhirat yang jauh lebih baik daripada apa yang ada di dunia. Demikianlah metode pembentukan kepribadian Islami menurut Syaikh Taqiyuddin anNabhani pada seseorang.

\section{Metode Pembentukan Kepribadian Islami dalam Pendidikan}

Menurut Syaikh Taqiyuddin anNabhani, tujuan pendidikan adalah dalam rangka membentuk kepribadian islami serta membekalinya dengan berbagai ilmu dan pengetahuan yang berhubungan dengan kehidupan (An-nabhani, 2001). Membentuk kepribadian islami, yaitu dengan membentuk pola pikir (aqliyah) dan pola sikap (nafsiyah) dengan cara menanamkan tsaqofah Islam berupa akidah, pemikiran, dan perilaku islami kedalam akal dan jiwa anak didik (Yasin, 2004). Sedangkan membekalinya dengan berbagai ilmu dan pengetahuan yang berhubungan dengan kehidupan adalah dengan mempersiapkan anak-anak didik agar diantara mereka menjadi ulama-ulama yang ahli di setiap aspek kehidupan, baik ilmu-ilmu keislaman berupa tafsir, fikih, peradilan Islam, ijtihad dan lainnya, maupun ilmu-ilmu terapan berupa, teknik, kimia, fisika, kedokteran dan lainnya (Yasin, 2004).

Dalam mewujudkan tujuan pendidikan tersebut, yaitu membentuk kepribadian islami pada peserta didik. Maka ada beberapa metode yang harus dilakukan yaitu: Pertama, menyusun kurikulum yang sesuai dengan tujuan tersebut. Kedua, menjadikan akidah Islam sebagai landasan materi pelajaran. Ketiga, menggunakan metode talaqqiyan fikriyan dalam pengajaran. Inilah metode pembentukan kepribadian islami dalam pendidikan. Kemudian ketiga metode ini dijelaskan sebagai berikut:

a) Kurikulum Pendidikan Berdasarkan Akidah Islam

Menurut Syaikh Taqiyuddin anNabhani, kurikulum pendidikan wajib berlandaskan akidah Islam. Seluruh mata pelajaran dan metode pengajaran dalam pendidikan disusun tanpa adanya penyimpangan sedikitpun dari akidah Islam (An-nabhani, 2001). Waktu pelajaran untuk ilmu-ilmu Islam dan bahasa Arab yang diberikan setiap minggu harus disesuaikan dengan waktu pelajaran untuk ilmu-ilmu lain, baik dari segi jumlah maupun waktu. Ilmu-ilmu terapan seperti olahraga harus dipisahkan dengan ilmu-ilmu tsaqofah. Ilmu-ilmu terapan diajarkan menurut kebutuhan dan tidak terikat dengan jenjang pendidikan tertentu (An-nabhani, 2001).

Tsaqofah Islam harus diajarkan disemua tingkat pendidikan dari 
mulai tingkat dasar sampai tingkat aliyah dan perguruan tinggi sesuai dengan rencana pendidikan yang tidak bertentangan dengan konsep dan hukum Islam. Sedangkan ilmu kesenian dan keterampilan dapat digolongkan sebagai ilmu pengetahuan, seperti perdagangan, pelayaran dan pertanian yang boleh dipelajari tanpa terikat batasan atau syarat tertentu; dan dapat juga digolongkan sebagai suatu kebudayaan apabila telah dipengaruhi oleh pandangan hidup tertentu, seperti seni lukis dan pahat yang tidak boleh dipelajari apabila bertentangan dengan pandangan Islam (An-nabhani, 2001).

Ditingkat perguruan tinggi semua ilmu-ilmu tsaqofah baik tsaqofah Islam maupun bukan boleh diajarkan secara utuh seperti halnya ilmu pengetahuan yang lain, dengan syarat tidak mengakibatkan adanya penyimpangan dari strategi dan tujuan pendidikan. Untuk tingkat perguruan tinggi dibuka berbagai jurusan dalam berbagai cabang ilmu keislaman, disamping diadakan jurusan lainnya seperti kedokteran, teknik, ilmu pengetahuan alam dan sebagainya (An-nabhani, 2001).

b) Menjadikan Akidah Islam sebagai Landasan Materi Pelajaran

Menurut Syaikh Taqiyuddin anNabhani, materi pelajaran harus berlandaskan kepada akidah Islam (An-nabhani, 2001). Berdasarkan hal ini, landasan setiap ilmu pengetahuan yang didapatkan anak didik baik pengetahuan yang terpancar dari akidah Islam, seperti pemikiran tentang akidah Islam dan hukum-hukum syara', maupun pengetahuan yang didasari atas akidah Islam, seperti sejarah, ekonomi, politik dan ilmu-ilmu lainnya, harus merujuk kepada akidah Islam. adapun yang dimasud dengan didasari atas akidah Islam adalah menempatkan akidah Islam sebagai standar. Jika bertentangan dengan akidah Islam, maka seorang muslim tidak boleh mengambil dan menyakininya. Selama tidak bertentangan dengan akidah Islam, maka seorang muslim boleh mengambilnya.

Akidah Islam adalah satusatunya asas, sebagai standar bagi seorang muslim dalam hal keyakinan dan perbuatan, untuk menilai apakah sesuatu dapat diambil atau harus ditinggalkan. Tidak ada larangan untuk mengenal akidah dan tsaqofah lain yang bertentangan dengan akidah Islam dan penyimpangan dari pemikiranpemikiran yang terpancar dari akidah Islam, asalkan terlebih dahulu memahami akidah Islam dengan keyakinan yang kuat dan mempelajari akidah serta tsaqofah asing bukan untuk diyakini dan diamalkan tetapi untuk membantahnya dan mengambil sikap syar'i terhadapnya (Annabhani, 2003).

c) Metode Pengajaran dengan Talaqqiyan Fikriyan

Menurut Syaikh Taqiyuddin anNabhani, metode pengajaran yang benar adalah dengan metode talaqqiyan fikriyan yaitu penyampaian pemikiran melalui perjumpaan antara pengajar dan pelajar (An-nabhani, 2003). Akal adalah aset yang Allah berikan kepada manusia. Dengan keberadaan akal, Allah memuliakan manusia dan menjadikannya sebab dibebankannya suatu hukum.

Akal terdiri dari empat komponen, yaitu otak sebagai tempat berfikir, penginderaan, fakta dan informasi yang terkait dengan 
fakta. akal berfikir dan memahami memiliki makna yang sama, yaitu menstransfer atau memindahkan fakta yang diserap oleh panca indera kedalam otak, kemudian fakta tersebut diinterpretasikan dengan informasi yang terkait, lalu ditetapkan hukum atas fakta tersebut. Karena itu ketika ingin menstransfer kepada anak didik, sebagaimana yang terjadi pada proses belajar mengajar, pengajar harus menstransfer pemikirannya melalui sarana yang bisa untuk menjelaskan, terutama bahasa. Pemikiran tersebut dihubungkan dengan fakta yang diserap oleh pelajar atau dengan fakta yang pernah diserap sebelumnya. Dengan demikian telah terjadi transfer pemikiran. Jika pemikiran tersebut tidak dihubungkan dengan fakta yang diserap atau dapat dirasakan, seperti menjelaskan makna unta tanpa bisa menggambarkan fakta yang terkait dengannya, maka tidak akan terjadi proses transfer pemikiran, yang terjadi hanya transfer informasi saja. Dengan informasi yang ditransfer tersebut anak didik hanya menjadi orang yang belajar, bukan orang yang berpikir. Dengan demikian seorang pengajar harus dapat memberikan gambaran yang mendekati fakta/realita tersebut kepada anak didik ketika menyampaikan suatu konsep atau ide, sehingga dapat dihubungkan dengan fakta/realita yang dirasakannya atau tergambar dibenaknya. Berdasarkan hal ini, anak didik menerimanya sebagai sebuah pemikiran (An-nabhani, 2003).

Fakta yang dapat diserap dalam pegajaran adalah adalah fakta yang dapat diindera melalui salah satu panca indera, baik fakta itu berbentuk materi atau immateri (maknawi). Fakta yang berbentuk materi contohnya adalah dinderanya pohon melalui penglihatan, suara burung melalui pendengaran, halusnya kain dengan perabaan, aroma bunga dengan penciuman dan lezatnya madu dengan merasakan. Sedangkan fakta yang berbentuk immateri (maknawi), contohnya adalah keberanian, amanah, pengecut dan khianat. Diindera secara pemikiran yang didasarkan atas penampakan yang bersifat materi. Contohnya, seorang muslim dengan keteguhannya dalam menghadapi musuh walaupun berlipat ganda jumlah dan kesiapan musushnya, ia disebut pemberani. Sebaliknya, larinya seorang muslim dari medan perang disebut pengecut (An-nabhani, 2003).

Sedangkan fakta yang tidak dapat diindera, yaitu hal-hal ghaib. Manusia tidak mempunyai kemampuan untuk merasakan dengan salah satu panca inderanya di dunia, seperti adanya surga, neraka, 'arsy, dan sebagainya. Manusia tidk dapat berpikir melalui penginderaan, melainkan dengan cara mendapatkan informasi yang pasti kebenarannya melalui alQur'an dan hadits mutawatir. Dengan demikian, dalam proses pembelajaran yang berkaitan dengan pandangan hidup atau tsaqofah Islam, tidak hanya berhenti pada makna-makna bahasa saja. Materi pelajaran dipahami untuk dapat diletakkan pada fakta yang terkait, agar dapat mengambil sikap sesuai dengan yang dituntut oleh hukum syara', baik berupa tuntutan untuk mengerjakan maupun meninggalkan. Materi pelajaran seperti ini dipelajari agar dapat mengendalikan prilaku anak didik 
sesuai dengan hukum Islam (Annabhani, 2003). Berdasarkan hal ini, pendidikan bukan ditujukan untuk semata-mata kemewahan intelaktual, tetapi untuk membentuk kepribadian yang Islami, pola pikir dan jiwa Islami yang senantiasa berusaha untuk meraih keridhoan Allah, yang tercermin pada setiap perbuatan dan perkatannya.

Demikianlah metode pembentukan kepribadian islami dalam pendidikan menurut pandangan Syaikh Taqiyuddin anNabhani. Dengan metode ini diharapkan dapat membentuk peserta didik yang memiliki kepribadian islami, sehingga akan melahirkan generasi ummat Islam yang memiliki kepribadian islami pemimpin masa depan yang akan mengembalikan peradaban Islam.

\section{KESIMPULAN}

Metode

pembentukan

kepribadian islami secara umum dapat dilakukan dengan tiga metode yaitu, pertama menanamkan akidah Islam, kedua menanamkan tsaqofah Islam dan ketiga senantiasa membangun keterikatan aqliyah dan nafsiyah dengan akidah Islam dan tsaqofah Islam. Pananaman akidah Islam dan tsaqofah Islam dilakukan dengan dalil-dalil, baik itu dalil aqli maupun dalil naqli agar terbangun sebuah kayakinan yang bersifat pasti sehingga mampu membentuk kepribadian islami pada diri seseorang.

Metode

pembentukan kepribadian islami dalam pendidikan dilakukan dengan beberapa tiga metode yaitu: Pertama, menyusun kurikulum berdasarkan akidah Islam. Kedua, menjadikan akidah Islam sebagai landasan materi pelajaran. Ketiga, menggunakan metode talaqqiyan fikriyan dalam proses pembelajaran. Inilah metode pembentukan kepribadian islami dalam pendidikan.

Dengan metode pendidikan di atas, maka lembaga pendidikan akan mampu mencetak generasi Islam yang berkepribadian islami dan terbebas dari pengaruh tsaqofah asing yang akan meracuni akidah dan pemikiran generasi Islam. Metode ini adalah merupakan solusi atas permasalahan sistem pendidikan hari ini.

Inilah hasil dari penelitian terhadap pembentukan kepribadian islami menurut Syaikh Taqiyuddin an-Nabhani, semoga penelitian ini dapat bermanfaat khususnya bagi penulis dan umumnya untuk seluruh kaum muslimin, baik dalam lingkup keluarga, pendidikan dan negara. Meskipun penulis sadari dalam penelitian ini masih banyak kekurangan-kekuranngnya.

\section{DAFTAR PUSTAKA}

Abdurrahman Hafiz. 2007. Diskursus Islam Politik dan Spiritual. Bogor: al-Azhar Press.

Abdurrahman, Hafidz. 2011. Membangun Pemikiran Cemerlang, Cet, ke-2, Bogor: Pustaka Thariqul Izzah.

Adz-Dzakiey, Hamdani Bakran. 2006. Psikologi Kenabian, Yogyakarta: Daristy.

Ahyadi Abdul Aziz. 1987. Psikologi Agama, Bandung: Sinar Baru.

Al-Qur'an, 2010. Kementrian Agama RI, Syaamil Qur'an.

An-Nabhani, Taqiyuddin, 2002. AdDaulatul al-Islamiyah, Cet. ke7, Libanon: Dar al-Ummah.

2001. Nizham al-Islam, Jakarta: Min Mansurati Hizbut Tahrir. 
Al-Fikra: Jurnal IImiah Keislaman, Vol. 17, No. 2, Juli - Desember, 2018 (279323)

2003. asySyakhshiyyah al-Islamiyyah, Cet. ke-VI, Libanon: Dar alUmma.

$\begin{array}{rr} & 2010 . \\ \text { Mafahim Hizb } & \text { at-Tahrir, }\end{array}$ Jakarta: Min Mansurati Hizbut Tahrir:

An-Nawawi, Muhammad, al-Jawi, Syarh Kasifah as-Saja'ala Safinah an-Naja. Semarang: Toha Putra, tt.

Arifin Muzayyin. 2008. Filsafat Pendidikan Islam. Jakarta: Bumi Aksara.

Dodiman, M.Ali. 2012. Memoar Pejuang Syariah dan Khilafah. Bogor: al-Azhar Fresh Zone.

Hamzah Ahmad dan Nanda Santoso. 1996. Kamus Pintar Bahasa Indonesia, Surabaya: Fajar Mulya.

Husen, Abdullah Muhammad. 2006. Studi Dasar-Dasar Pemikiran Islam, Cet, ke-V, Bogor: Pustaka Thariqul Izzah

Muhsin Rodhi, Muhammad, 2012. Tsaqofah dan Metode Hizbut Tahrir dalam Mendirikan Negara Khilafah, Bogor: alAzhar Fresh Zone.

Mujib, Abdul. 1999, Fitrah dan Kepribadian Islam, Jakarta: Darul Fatah.

Mujib, Abdul. 2007. Kepribadian dalam Psikologi Islam, Jakarta: PT. Grafindo Persada.

Purwanto Yadi. 2007. Psikologi Kepribadian, Bandung: Refika Aditama.

Riyadh, Saad. 2007. Jiwa dalam Bimbingan Rasulullah, Jakarta: Gema Insani Press.

Sumadi Suryabrata. 1993. Psikologi Kepribadian, Jakarta: Raja Grafindo Persada.
Yasin, Abu. 2004. Usus at-Ta'lim fi Daulah al-Khilafah, Dar alUmmah. 